\title{
The distribution of depleted uranium contamination in Colonie, NY, USA
}

\author{
N. S. Lloyd ${ }^{1 *}$, S. R. N. Chenery ${ }^{2}$, R. R. Parrish ${ }^{1,3}$ \\ ${ }^{1}$ Department of Geology, University of Leicester, University Road, Leicester, LE1 \\ 7RH, UK. \\ ${ }^{2}$ British Geological Survey, Kingsley Dunham Centre, Keyworth, Nottingham, NG12 \\ $5 G G$, UK. \\ ${ }^{3}$ NERC Isotope Geosciences Laboratory, Kingsley Dunham Centre, Keyworth, \\ Nottingham, NG12 5GG, UK. \\ *email: nsl3@alumni.leicester.ac.uk \\ Published: Science of the Total Environment (Lloyd et al. 2009a). \\ Submitted 03/07/2009, accepted 14/09/2009 \\ Keywords: depleted uranium, DU, particulate, isotope ratio, ICP-MS, soils
}

\begin{abstract}
Uranium oxide particulates were dispersed into the environment from a factory in Colonie (NY, USA) by prevailing winds during the 1960's and '70's. Uranium concentration and isotope ratios from bulk soil samples have been accurately measured using inductively coupled plasma quadrupole mass spectrometry (ICP-QMS) without the need for analyte separation chemistry. The natural range of uranium concentrations in the Colonie soils has been estimated as $0.7-2.1 \mu \mathrm{g} \mathrm{g}^{-1}$, with a geometric mean of $1 \mu \mathrm{g} \mathrm{g}^{-1}$; the contaminated soil samples comprise uranium up to $500 \pm 40 \mu \mathrm{g} \mathrm{g}^{-1}$. A plot of ${ }^{236} \mathrm{U} /{ }^{238} \mathrm{U}$ against ${ }^{235} \mathrm{U} /{ }^{238} \mathrm{U}$ isotopes ratios describes a mixing line between natural uranium and depleted uranium (DU) in bulk soil samples; scatter from this line can be accounted for by heterogeneity in the DU particulate. The end-member of DU compositions aggregated in these bulk samples comprises $(2.05 \pm 0.06) \times 10^{-3}{ }^{235} \mathrm{U} /{ }^{238} \mathrm{U},(3.2 \pm 0.1) \times 10^{-5}{ }^{236} \mathrm{U} /{ }^{238} \mathrm{U}$, and $(7.1 \pm 0.3) \times 10^{-6}$ ${ }^{234} \mathrm{U} /{ }^{238} \mathrm{U}$. The analytical method is sensitive to as little as $50 \mathrm{ng} \mathrm{g}^{-1}$ DU mixed with the natural uranium occurring in these soils. The contamination footprint has been mapped northward from site, and at least one third of the uranium in a soil sample from the surface $5 \mathrm{~cm}$, collected $5.1 \mathrm{~km} \mathrm{NNW}$ of the site, is DU. The distribution of contamination within the surface soil horizon follows a trend of exponential decrease with depth, which can be approximated by a simple diffusion model. Bioturbation by earthworms can account for dispersal of contaminant from the soil surface, in the form of primary uranium oxide particulates and uranyl species that are sorbed to organic matter. Considering this distribution, the total mass of uranium contamination emitted from the factory is estimated to be c. 4.8 tonnes.
\end{abstract}

\section{Introduction}

The by-product of uranium enrichment, where the fissile isotope ${ }^{235} \mathrm{U}$ is artificially concentrated for use as nuclear fuel or weapons, is depleted uranium (DU). In contrast to natural uranium, DU typically comprises $(2-3) \times 10^{-3}{ }^{235} \mathrm{U} /{ }^{238} \mathrm{U}$, is also depleted in ${ }^{234} \mathrm{U}$, and is contaminated by anthropogenic ${ }^{236} \mathrm{U}$ from reprocessed uranium (Bleise et al. 2003). Worldwide nuclear programmes have amassed c. 1.2 million tonnes of DU, most of which is stored as UF $_{6}$ (NEA \& IAEA 2001). Applications for depleted uranium metal include ballast, munitions and radiation shielding. The use of armour piercing DU munitions (kinetic energy penetrators) in the Gulf and Balkans conflicts, and recently the Iraq invasion has been highly controversial, because they disperse a radioactive and toxic material into the environment. However, DU exposure is unlikely to present a significant health risk (e.g. Priest 2001).

The Royal Society $(2001 ; 2002)$ reports focus on the health risks from inhalation of DU particulates. The reports recommended that the environmental behaviour of alloys and particles of DU, 
should be compared to natural uranium minerals, and information should be obtained on their bioavailability.

Several recent studies have investigated the environmental behaviour of DU metals, which corrode in oxidising environments to form soluble uranyl species (e.g. Buck et al. 2004; Schimmack et al. 2005; Fomina et al. 2008; Handley-Sidhu et al. 2009). The DU particulates released from munitions impacting armour are characterised in Krupka et al. (2009) and other papers in Health Physics 96 (3) resulting from the Capstone Aerosols study (Parkhurst et al. 2004). These and the particulates from the combustion of DU metals are introduced to the environment in a range of oxidation states: $\mathrm{UO}_{2}-\mathrm{UO}_{2+\mathrm{x}}-\mathrm{U}_{3} \mathrm{O}_{8}-\mathrm{UO}_{3}$. $\mathrm{UO}_{3}$ and uranyl species are thermodynamically favoured, but bulk oxidation to these more soluble oxides is limited by slow kinetics and surface passivation (McEachern \& Taylor 1998). This appears to be the case for the persistence of low solubility $\mathrm{UO}_{2+\mathrm{x}}$ (hyperstoichiometric $\mathrm{UO}_{2}$ ) and $\mathrm{U}_{3} \mathrm{O}_{8}$ particles in soils (Chapter 3 / Lloyd et al. 2009b). Radiogenic lead reduces the mobility of uranium from natural uraninite (e.g. Finch \& Ewing 1992), which otherwise is a logical analogue. Studies by Oliver et al. (e.g. 2008) have recently made environmental observations on the distribution of contamination from DU munitions test firing. A number of other studies have characterised individual particles from environmental samples contaminated by the combustion of uranium metals and DU munitions (e.g. Török et al. 2004; Salbu et al. 2005; Lind et al. 2009).

This aim of this environmental case-study is to identify the processes that affect the distribution and bioavailability of uranium from DU particulate contamination. The field site offers an accessible and large contamination footprint, with the absence of confounding contamination from DU metal fragments, and more than 25 years of environmental processing. It is therefore an attractive analogue for battlefield contamination, and potentially for epidemiological studies related to DU particulate inhalation exposure.

Natural uranium comprises three isotopes: ${ }^{238} \mathrm{U},{ }^{235} \mathrm{U}$ and ${ }^{234} \mathrm{U}$, all of which are unstable with long half-lives. The 'convention' value for ${ }^{235} \mathrm{U} /{ }^{238} \mathrm{U}$ (atom ratio, $n^{235} \mathrm{U} / n^{238} \mathrm{U}$ ) is $7.253 \times 10^{-3}$ (Steiger \& Jäger 1977), recently recommended as $7.257 \times 10^{-3}$ (De Laeter et al. 2003), with slight (\%o) natural fractionation about this value (Weyer et al. 2008). Except for the Oklo natural reactors (Neuilly et al. 1972) deviation of ${ }^{235} \mathrm{U} /{ }^{238} \mathrm{U}$ implies anthropogenic contamination. Uranium in secular equilibrium has $\mathrm{a}^{234} \mathrm{U} /{ }^{238} \mathrm{U}$ ratio of $5.5 \times 10^{-5}$ (Richter et al. 1999), but there are significant natural deviations from this ratio (e.g. Fleischer 2008). The abundance of ${ }^{236} \mathrm{U}$ in natural uranium is negligible (e.g. Berkovits et al. 2000).

The distribution of uranium within the Earth is discussed in Plant and Saunders (1996), the continental crust comprises an average $2.7 \mu \mathrm{g} \mathrm{g}^{-1}$ (Taylor 1964), hosted in resistate igneous accessory minerals including thorite, monzanite and zircon, and occasionally concentrated in ore minerals including uraninite and pitchblende (impure uranium oxides), and coffinite (a hydrated uranium silicate). The natural background concentration is variable in environmental samples, typically low $\mu \mathrm{g}$ $\mathrm{g}^{-1}$ and $\mathrm{ng} \mathrm{g}^{-1}$ levels.

As discussed previously, natural environmental samples comprise variable trace quantities of uranium, but anthropogenic contamination can be determined from ${ }^{235} \mathrm{U} /{ }^{238} \mathrm{U}$. Analytical methods for determining uranium in environmental samples were reviewed in Wolf (1999), the precision of radiometric techniques is often limited by the low activities of the uranium isotopes. Mass spectrometry techniques can achieve good precision, especially for isotope ratios. Isotope dilution thermal ionisation mass spectrometry (ID-TIMS) offers the best precision, but is costly and requires 
laborious sample preparation. Taylor et al. (1998) obtained relative uncertainties of $0.2 \%(\mathrm{k}=2)$ for ${ }^{235} \mathrm{U} /{ }^{238} \mathrm{U}$ from soil samples using single-spike ID-TIMS.

The performance of four inductively coupled plasma mass spectrometers (ICP-MS, multi and single collector sector field, and quadrupole) in combinations with several nebulisers (ultrasonic and desolvating), measuring ${ }^{236} \mathrm{U} /{ }^{238} \mathrm{U}$, are compared in Boulyga et al. (2002). The multicollector ICP-MS (MC-ICP-MS) achieved excellent precision; and the desolvating nebuliser reduced hydride interference by up to two orders of magnitude. Quadrupole ICP-MS (ICP-QMS) instruments offer lower costs with generally good precision. As for most ICP techniques, sample dissolution is required. Analyte separation chemistry is often preferred (e.g. Zheng \& Yamada 2006), but it is desirable to avoid this costly step. Other than hydride, there appears to be little potential for polyatomic interferences on the uranium isotopes (Lariviere et al. 2006). Ehrlich et al. (2004) found analyte separation to be unnecessary for ${ }^{234} U /{ }^{238} U$ measurements from manganese nodules, although deposition of dissolved solids on the sampler and skimmer cones could be an issue. However, Gwiazda et al. (2004) and Shen et al. (2002) experienced background interferences on $\mathrm{m} / \mathrm{z} 235$ when working at very low uranium concentrations; the latter study attributed this to organic rich samples and the interference was removed by separation chemistry.

A significant objective of this case-study is to define the present distribution of DU contamination. ICP-QMS was used for the determination of uranium isotope ratios from trace concentrations in contaminated soil samples. Adequate precision was realised using a desolvating nebuliser, and without the need for analyte separation chemistry. There is heterogeneity in the isotopic composition of DU contaminant (Chapter 5 / Lloyd et al. 2009c) and the effect of this variability on the isotopic compositions of bulk environmental samples is explored in this paper. The dataset demonstrates the clarity for resolving DU contamination that precise ${ }^{235} U /{ }^{238} U$ ratios coupled with high productivity offer.

\section{The Colonie case-study}

\subsection{Site history}

National Lead Industries (NLI) operated a factory in Colonie (NY, USA), from 1958 - 1984. The factory reduced $\mathrm{UF}_{4}$ to metal, and machined depleted uranium articles including kinetic energy penetrators, counterweights and radiation shielding (ATSDR 2004). The storage of scrap uranium metal is hazardous, because this material is pyrophoric when it is finely divided. Therefore, this waste was converted to uranium oxides in a furnace, which resulted in emissions of uranium oxide aerosols to the atmosphere. This was not contemporary best practice (Wilkinson 1962). National Lead were also responsible for uranium contamination surrounding the Fernald site in Ohio (Buck et al. 1996).

The history of permits for the NLI site is documented in a draft report by the New York State Department of Health (1979). In 1968, it was noted that the converter stack operated without filtration, and immediately south of the site ${ }^{238} \mathrm{U}$ soil concentrations of $163 \mu \mathrm{g} \mathrm{g}{ }^{-1}$ were reported; Department of Labour permitted nearly $600 \mu \mathrm{g} \mathrm{g}^{-1}$ on site at that time. In $1973 \mathrm{NLI}$ were permitted to discharge a total of $3.9 \mathrm{~kg}$ of uranium from 23 stacks. In 1975 the site was limited to handling natural and depleted uranium, but prior to this licences were also held for enriched uranium and thorium. In 1977, when production increased, an electrostatic precipitator was added to the conversion furnace (chip-burner), although this was reportedly bypassed (NYSDOH 1979; Romano 1982).

In May 1979 routine analysis of air filters, sampled at locations 40.8 and $15.7 \mathrm{~km} \mathrm{NNW}$ of the NLI site, revealed contamination by micrometer diameter DU particles (Dietz 1980). A survey 
conducted later that year revealed extensive depleted uranium contamination of soils surrounding the site (Jeter \& Eagleson 1980). The legal proceedings that led to the closure of NLI for excessive emissions of uranium to the environment are detailed in Romano (1982).

In 1984, US Department of Energy took over responsibility for the site, and since 1997 the U.S. Army Corps of Engineers has been responsible for the environmental remediation of the site under the Formerly Utilized Site Remedial Action Program (USACE 2009). The remediation threshold used for soils is $35 \mathrm{pCi} \mathrm{g}^{-1}$ from ${ }^{238} \mathrm{U}$ (USACE 2002), equivalent to $104 \mu \mathrm{g} \mathrm{g}^{-1}$, highly conservative when compared to $190 \mathrm{pCi} \mathrm{g}^{-1}$ derived by Dunning (1996). Remediation of the site and limited remediation of surrounding properties, involving removal and disposal of contaminated soils, is reported to have cost US\$ 190 million (Dlouhy 2009).

Contamination is evident in reservoir sediments at a site downstream of NLI (Arnason \& Fletcher 2003; Lo et al. 2006; Arnason et al. 2008). Depleted uranium has been detected in the urine of former employees (with enriched uranium from one individual) and from some residents (Parrish et al. 2008).

Examination of contaminated soils and dusts reveals primary uranium oxide particles in the size range $0.5-150 \mu \mathrm{m}$, including mixed $\mathrm{UO}_{2+\mathrm{x}}$ and $\mathrm{U}_{3} \mathrm{O}_{8}$ spheres with diameters $20-64 \mu \mathrm{m}$, and rarely secondary uranium precipitates (Chapter 3 / Lloyd et al. 2009b). These spheres and other specific particle morphologies are directly comparable to those from munitions. Laser ablation (LA-) MC-ICPMS reveals a spread of depleted uranium isotope ratios from individual particles, attributed to variations in the NLI feedstocks (Chapter 5 / Lloyd et al. 2009c).

\subsection{Environmental setting}

The NLI site is located between Colonie and Albany, NY, USA (Figure 1). The NLI site neighbours other industrial sites, and is close to two busy roads and a railway, the surrounding area (within $3 \mathrm{~km}$ ) is mainly suburban with gentle topography. Construction of highway I90, State University of New York (SUNY) Albany campus, and the Harriman Campus during the 1960s relandscaped much of the area within a $2 \mathrm{~km}$ quadrant $\mathrm{SW}$ of NLI. 


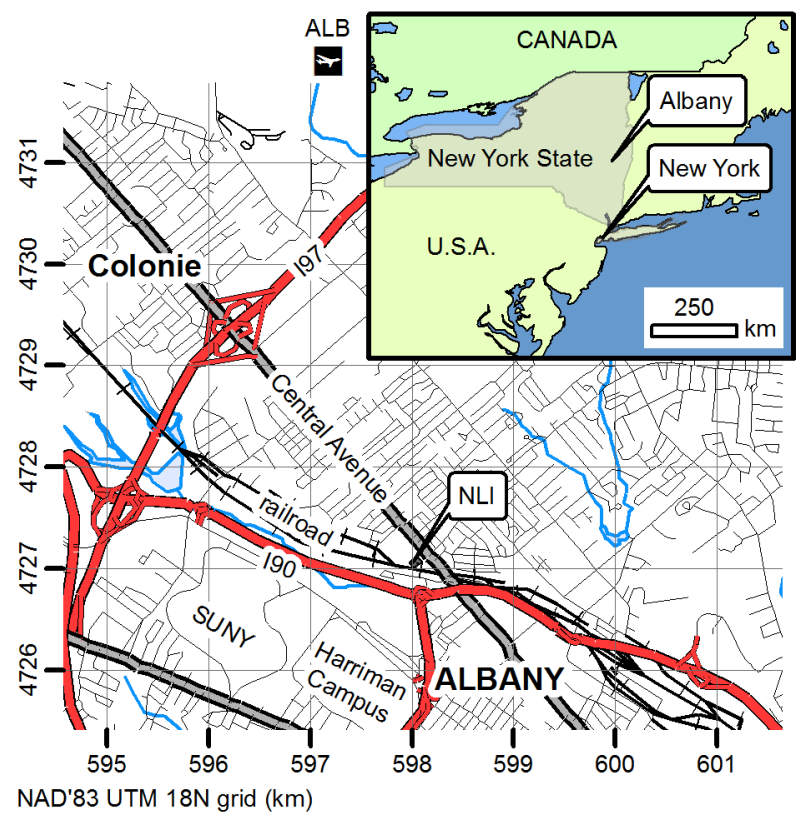

Figure 1. Location map for the NLI site, which is located between Colonie and Albany, NY, USA. Base map with permission (US Department of Commerce 2001).

The soils within $3 \mathrm{~km}$ of NLI are dominated by generally well-drained loamy fine sands; with little pedogenic horizon development, less than $14 \mathrm{wt}$. \% clay, acid $\mathrm{pH}$ and negligible carbonate content (USDA 2006). The soil samples collected for this study had a pH range of $3.2-7.6$, median $5.3(\mathrm{n}=208)$. There is typically a thin, $<1 \mathrm{~cm}$, leaf litter layer covering a $15-25 \mathrm{~cm}$ thick organicrich mineral-sand horizon (A). These soils are derived from aeolian dune deposits (well sorted silica rich fine-sands), kame deposits, lacustrine sands and some clays, which overlie the Normanskill Shale of the Middle Ordovician (NYS Geological Survey 1999). The Colonie soils contain small quantities of detrital zircons, which host natural uranium.

The mean uranium concentration of 19 sediment samples from within $12 \mathrm{~km}$ of NLI, analysed by X-ray fluorescence for the NURE programme (USGS 2004), was $0.6 \mu \mathrm{g} \mathrm{g}^{-1}$. Uranium air concentrations for air samples collected in Albany in 1969 were c. $0.5 \mathrm{ng} \mathrm{m}^{-3}$, or $5 \mu \mathrm{g} \mathrm{g}^{-1}$ of total suspended particulate (concentrated relative to sediments), within the range of those reported from elsewhere in New York State (McEachern et al. 1971).

Vegetation in the area includes deciduous and coniferous woodlands, and the native Albany Pine Bush ecosystem including pitch pine (Albany Pine Bush Preserve Commission 2005). The Köppen-Geiger climate zone is Dfa, "cold, without dry season, hot summer" (Peel et al. 2007).

In addition to depleted uranium, the NLI site has also handled other hazardous materials including enriched uranium, thorium, heavy metals (including $\mathrm{Pb}, \mathrm{Ni}, \mathrm{Sb}$ and $\mathrm{Cd}$ ) and polychlorinated biphenyl (PCB) oils. Some of these materials were dumped into a lake that adjoined the NLI site (ATSDR 2004). A 'US Superfund' site, remediated for mercury and PCB oil contamination is located approximately $900 \mathrm{~m}$ WNW of NLI (EPA 1983). The Patroon creek, which runs parallel to highway I90 and into which NLI discharged waste water via a culvert, was previously classified as one of the ten most severely polluted streams in New York State (refs. in Arnason \& Fletcher 2003). 


\subsection{Background data}

In 1979 NLI were required to commission a survey of soils surrounding the Colonie site. Surface soil samples $(0-1.3$ and $1.3-5.1 \mathrm{~cm})$ from within $600 \mathrm{~m}$ of NLI were analysed by gammaray spectrometry and reported in Jeter and Eagleson (1980). The gamma-ray spectrometry data have poor precisions, typically $\pm 32 \%$ for ${ }^{235} \mathrm{U} /{ }^{234} \mathrm{Th} \approx{ }^{235} \mathrm{U} /{ }^{238} \mathrm{U}$. The ${ }^{234} \mathrm{Th}$ activity data $( \pm 14 \%$ ) have been converted to uranium concentrations, which have been interpolated by ordinary kriging using ESRI Geostatistical Analyst (Johnston et al. 2001), and are presented in Figure 2.

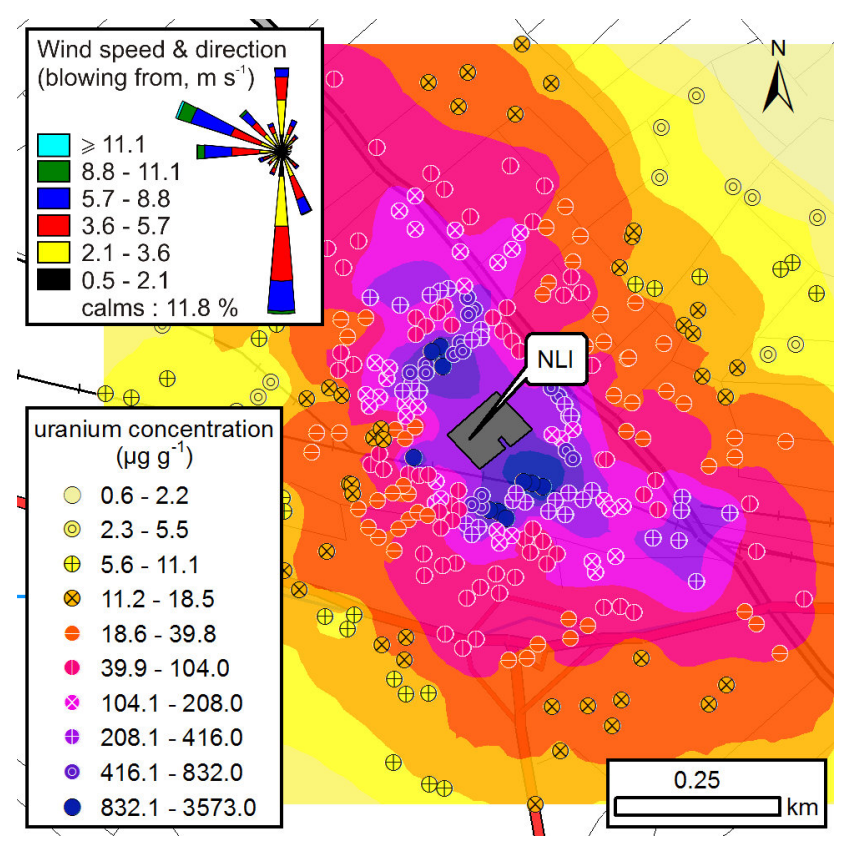

Figure 2. Ordinary kriging of 1979 soil survey data (log-transform, quadratic trend removal, exponential semivariogram model; cross validation statistics: mean standardised error $0.004 ; \mathrm{RM}^{2}$ standardised error 0.98 ). The distribution of uranium was clearly controlled by the prevailing winds. From this interpolated dataset, it is estimated that c. 3.2 tonnes of uranium contaminated the surface $5.1 \mathrm{~cm}$ of soils within $600 \mathrm{~m}$ of NLI. Wind rose from Albany County Airport data, 1961 - 1979 (WebMet.com 2002; Lakes 2005).

The areal distribution of uranium surrounding NLI was clearly controlled by the prevailing winds; and can be attributed to aerial deposition of uranium particulate emissions. The total mass of contaminant uranium in the surface soils, to a depth of $5.1 \mathrm{~cm}$ and a distance of $600 \mathrm{~m}$ from NLI, is estimated in the order of 3.2 tonnes $^{1}$ (from the integration of the interpolated dataset, with an estimated $0.8 \pm 0.1 \mathrm{~g} \mathrm{~cm}^{-3}$ dry unconsolidated soil density, and a mean natural background of $1 \mu \mathrm{g} \mathrm{g}^{-1}$ uranium). The natural background is determined in Section 5.2, and the mass beneath $5.1 \mathrm{~cm}$ is estimated in Section 5.3.

To place this in context, the natural uranium in this volume of soil is approximately $54 \mathrm{~kg}$. The Colonie contamination is significant compared to 321 tonnes DU deployed during the Gulf War (Bleise et al. 2003) of which a small fraction was aerosolised and spread over numerous locations.

${ }^{1}$ It is difficult to calculate the uncertainty involved in this figure; it was estimated to be in the order of \pm 0.5 tonnes. 
These quantities are small compared to the emissions of heavy metals from large smelters, e.g. Rawlins et al. (2006) estimated that 2500 tonnes of lead particulates contaminated Humberside (UK).

The NLI contamination footprint equates to an average $2 \mathrm{~g} \mathrm{~m}^{-2}$ deposition over the 1979 survey area, but is substantially concentrated towards the site. Approximately $49 \%$ was deposited within 200 $\mathrm{m}$ of NLI, and $80 \%$ within $400 \mathrm{~m}$. Our previous estimate of 5 tonnes incorrectly assumed a higher soil density (Parrish et al. 2008). It is apparent that annual discharges of $3.9 \mathrm{~kg}$ permitted in 1973 were not typical of the plant's history, averaging $139 \mathrm{~kg}$ per annum from $1958-1981$.

\section{Methodology}

\subsection{Sampling}

Soil sampling was conducted during 2006 and 2007. Due to the limited number of easily accessible and apparently undisturbed sampling locations, it was not possible to follow a designed sampling strategy for this study, i.e. sampling had to be more ad hoc. Most of the sampling locations in this suburban environment were in wooded areas, scrubland and on public land. A number of areas are either less accessible, or they have been substantially re-landscaped during the 1960s, e.g. Albany International Airport, the Harriman Campus, University at Albany (SUNY), I90, and the more densely populated neighbourhood south of I90 (see Figure 1).

Soil samples were collected using a cleaned hand-auger, after removal of vegetation and leaf litter from the soil surface. The top $5 \mathrm{~cm}$ was bagged separately to the remaining $5-15 \mathrm{~cm}$ sample. Thus, the samples are mainly organic rich loamy fine sands (A horizon). For each location, a sample was collected from five points over a ten-metre square, totalling approximately $0.5 \mathrm{~kg}$ soil. Sampling duplicates were taken from approximately one in ten locations, from an offset square. Soil profiles were sampled by digging a pit and collecting from a cleaned surface.

\subsection{Sample preparation and dissolution}

Soils samples were dried at $40-60{ }^{\circ} \mathrm{C}$ for $24-72$ hours, sieved to less than $2 \mathrm{~mm}$, and split into two subsamples. A $60 \mathrm{~g}$ aliquot from each sample was ground to a fine powder in an agate ball mill (aiming for $<63 \mu \mathrm{m}$ grain size).

The aim of the sample digestion methodology (after Green 2007) is for total dissolution. For each digestion, one gram of the powdered soil was weighed into an acid-leached PFA vessel (Savillex), $20 \mathrm{ml}$ of concentrated $\mathrm{HNO}_{3}$ was added, the vessel sealed and refluxed at $120{ }^{\circ} \mathrm{C}$ for 8 hours, then opened and evaporated. $8 \mathrm{ml}$ of $\mathrm{HNO}_{3}, 4 \mathrm{ml} \mathrm{HClO}_{4}$ and $10 \mathrm{ml} \mathrm{HF}$ were added to each vessel, which was heated to $80{ }^{\circ} \mathrm{C}$ for 8 hours, before being evaporated to near-dryness at $160{ }^{\circ} \mathrm{C}$. The contents were dissolved in $10 \mathrm{ml} 50 \% \mathrm{HNO}_{3}$ and $10 \mathrm{ml} \mathrm{H}_{2} \mathrm{O}_{2}$, and then diluted to $100 \mathrm{ml}$ (i.e. $1 \%$ soil in a $5 \% \mathrm{HNO}_{3}$ matrix). Prior to analysis, the solutions were diluted to $0.1 \%$ or less in $1 \% \mathrm{HNO}_{3}$. Typical digestion blank levels are c. 4 ng uranium (using BDH Aristar analytical grade reagents and MilliQ $18 \mathrm{M} \Omega$ deionised water).

Prior to MC-ICP-MS analysis, uranium was separated from a sub-set of the soil solutions. The solutions were adjusted to $4 \mathrm{M} \mathrm{HNO}_{3}$ (double quartz distilled), and then pipetted onto pre-leached dipentyl pentylphosphonate (Eichrom Industries UTEVA, described Horwitz et al. 1992). The uranium was then eluted using $0.6 \mathrm{M} \mathrm{HCl}$, this solution was evaporated to dryness, $\mathrm{H}_{2} \mathrm{O}_{2}$ was added and then evaporated, and finally dissolved in $1 \mathrm{ml} 2 \% \mathrm{HNO}_{3}$. Typical laboratory blanks for the separation chemistry in the class 100 clean room are $<100 \mathrm{fg}$ uranium. 


\subsection{Analytical}

The diluted sample digests were analysed at the British Geological Survey (Keyworth, UK) using ICP-QMS (VG Elemental Excell). Concentrations were determined in a separate run to the isotope ratios, using external multi-element standards $\left(2,5,10 \mathrm{ng} \mathrm{ml}^{-1}\right.$ concentration) and an internal Re monitor solution added by T-piece prior to nebulisation (concentric flow, $1 \mathrm{ml} \mathrm{min}^{-1}$ ).

For isotope ratio analysis, the sample digests were diluted to achieve 0.6 - 1 million counts per second from ${ }^{238} \mathrm{U}$ on the ion counter (typically from $1-4 \mathrm{ng} \mathrm{ml}^{-1}$ at $0.1 \mathrm{ml} \mathrm{min}^{-1}$ ). A desolvating nebuliser (Cetac Technologies Aridus II) was used for isotope ratio runs, to minimise hydride interference and maximise sensitivity. Analytical runs were limited to about 60 sample solutions due to fouling of the Ni sampler and skimmer cones, which significantly reduced sensitivity. However, these can be cleaned for less cost than analyte separation chemistry.

Natural uranium solutions were used as external standards (US Geological Survey SDO-1 or Institute for Reference Materials and Measurements REIMEP 18-A). The instrument was operated in peak jumping mode, acquiring 15 measures integrated from 920 sweeps across $m / z$ 233, 234, 235, 236 \& 238, with dwell times of 5 milliseconds. Blank, hydride and mass-bias corrections were applied to the data. In actuality the hydride correction from $\mathrm{m} / \mathrm{z} 236 / \mathrm{m} / \mathrm{z} 235$, typically c. $10^{-5}$, is convolved with abundance sensitivity from ${ }^{238} \mathrm{U}$ peak tails (not measured), but is not significant to the reported data. The mass bias, typically c. $0.3 \%$ for ${ }^{235} \mathrm{U} /{ }^{238} \mathrm{U}$ and assumed linear with mass, is the significant correction. Uncertainty $(\mathrm{k}=2)$ was propagated from the instrumental standard error of the mean $(\mathrm{n}=$ 15 ) and the relative standard deviations of the corrected QC solutions.

A subset of the soil samples were analysed at the NERC Isotope Geosciences Laboratory (Keyworth, UK) using MC-ICP-MS (VG Elemental Axiom) with a desolvating nebuliser (Cetac Technologies Aridus), after separation of the analyte uranium from its matrix. Abundance sensitivity, hydride, and mass-bias were corrected for using an external standard (U950A, natural uranium solution, assuming the convention value ${ }^{235} \mathrm{U} /{ }^{238} \mathrm{U} 7.253 \times 10^{-3}$ ).

Total carbon was measured in triplicate from infrared absorption by combustion gases (LECO CS230, Stockport, UK). Soil $\mathrm{pH}$ was measured from unmilled soils using a calibrated Pt electrode in a $1 \mathrm{~g}: 2.5 \mathrm{ml} 0.01 \mathrm{M} \mathrm{CaCl}_{2 \text { (aq) }}$ slurry.

Ordinary kriging was used to interpolate the sample data using ESRI Geostatistical Analyst (Johnston et al. 2001). A log transform was used for heavily skewed datasets, and a quadratic function for trend removal. The cross-validation error statistics were optimised by changing the semivariogram model, lag size, and 'neighbours included' parameters. Exponential semivariogram models and 8 sector 'neighbourhood searches' were appropriate because it was apparent from the data that contamination falls off exponentially and is directional (see Section 5.5). Reasonable cross-validation error statistics were achieved, and these are summarized with the methodology in the figure captions.

\section{Quality Control}

\subsection{Uranium concentrations}

The ICP-QMS concentration data for three quality control (QC) solutions are presented in Table 1. Reference materials SDO-1 (U.S. Geological Survey, shale powder, c. $9.7 \%$ organic carbon) and JR-2 (Geological Survey of Japan, rhyolite powder) were included in each digestion batch to monitor dissolution and analyte recovery. There is a slight, but minimal, positive bias for the independent multi-element standard. SDO-1 was underestimated by c. $4 \%$; JR-2 was within the expected range. 


\begin{tabular}{lll}
\hline \multicolumn{1}{c}{ QC solution } & $\mathbf{n}$ & \multicolumn{1}{c}{$\begin{array}{c}\text { uranium concentration } \\
\left(\boldsymbol{\mu g ~ g ~}^{-1} \text { or } \mathbf{~ g ~ m}^{-1}\right)\end{array}$} \\
\hline $\begin{array}{l}\text { 'QC-A** } \\
\text { target value }\end{array}$ & 53 & $\begin{array}{l}10.14 \pm 0.08 \\
10\end{array}$ \\
\hline SDO-1 & 9 & $46 \pm 1$ \\
reference value ** & & $47.9-48$ \\
\hline JR-2 & 12 & $11.7 \pm 0.3$ \\
reference value** & & $10.2-12.0$ \\
\hline
\end{tabular}

Table 1. Quality control data for the measured $Q C$ solutions. * $Q C-A$ is an independently prepared multi-element standard solution with a target concentration of 10

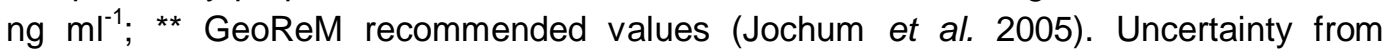
standard error of the mean $(\mathrm{k}=2)$.

A Thompson-Howarth duplicate control chart (Thompson \& Howarth 1978; amc 2002b) for the uranium concentration data is presented in Figure 3. The estimated analytical uncertainty is $\pm 8.8 \%$ (k $=2)$.

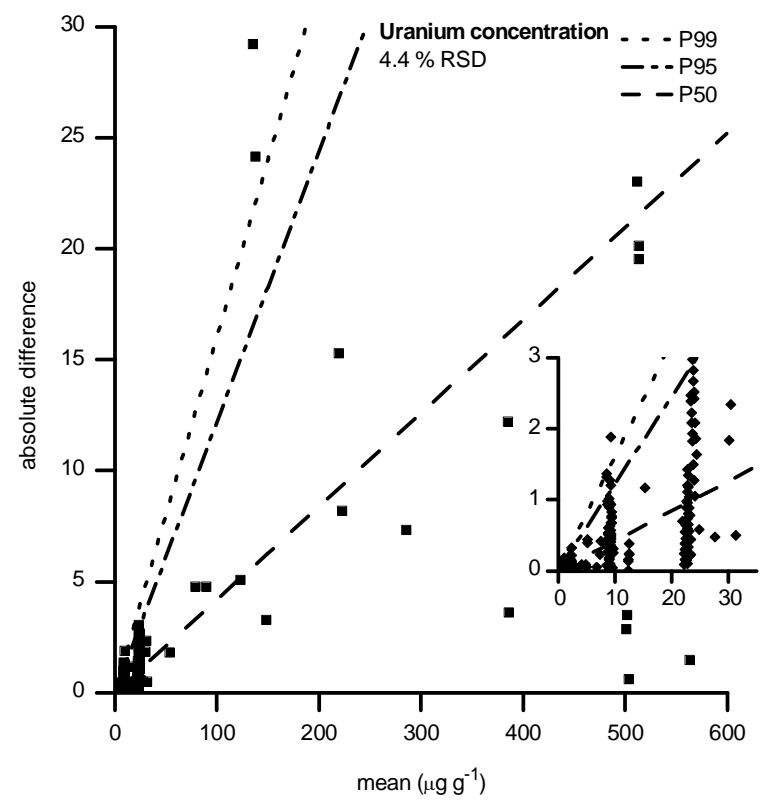

Figure 3. Thompson-Howarth duplicate control chart (Thompson \& Howarth 1978; amc 2002b) for uranium concentrations measured by ICP-QMS, which was used to estimate an RSD of $4.4 \%(k=1, n=189)$.

\subsection{Uranium isotope ratios}

The MSWD (Wendt \& Carl 1991) of the ${ }^{236} \mathrm{U} /{ }^{238} \mathrm{U}$ data from REIMEP 18-C suggested that the propagated uncertainties were underestimated, so these were expanded by $5 \%$. The lower limit of detection (LLD) for ${ }^{236} \mathrm{U} /{ }^{238} \mathrm{U}$ by ICP-QMS was estimated as $2 \times 10^{-6}$.

Thompson-Howarth duplicate quality control charts, suggested that ${ }^{235} \mathrm{U}^{238} \mathrm{U}$ uncertainty was underestimated using instrumental standard error; standard deviation appears more appropriate. This is possibly because for ${ }^{236} \mathrm{U}$ and ${ }^{234} \mathrm{U}$, precision is limited by counting statistics, but plasma noise may be significant for ${ }^{235} \mathrm{U}$. 
Thompson-Howarth duplicate quality control charts for the isotope ratio analyses are presented in Figure 4. These confirm that the expanded uncertainties are appropriate for the sample data. The typical relative uncertainty $(\mathrm{k}=2)$ of $1.8 \%$ for ${ }^{235} \mathrm{U} /{ }^{238} \mathrm{U}$ is adequate for this application.
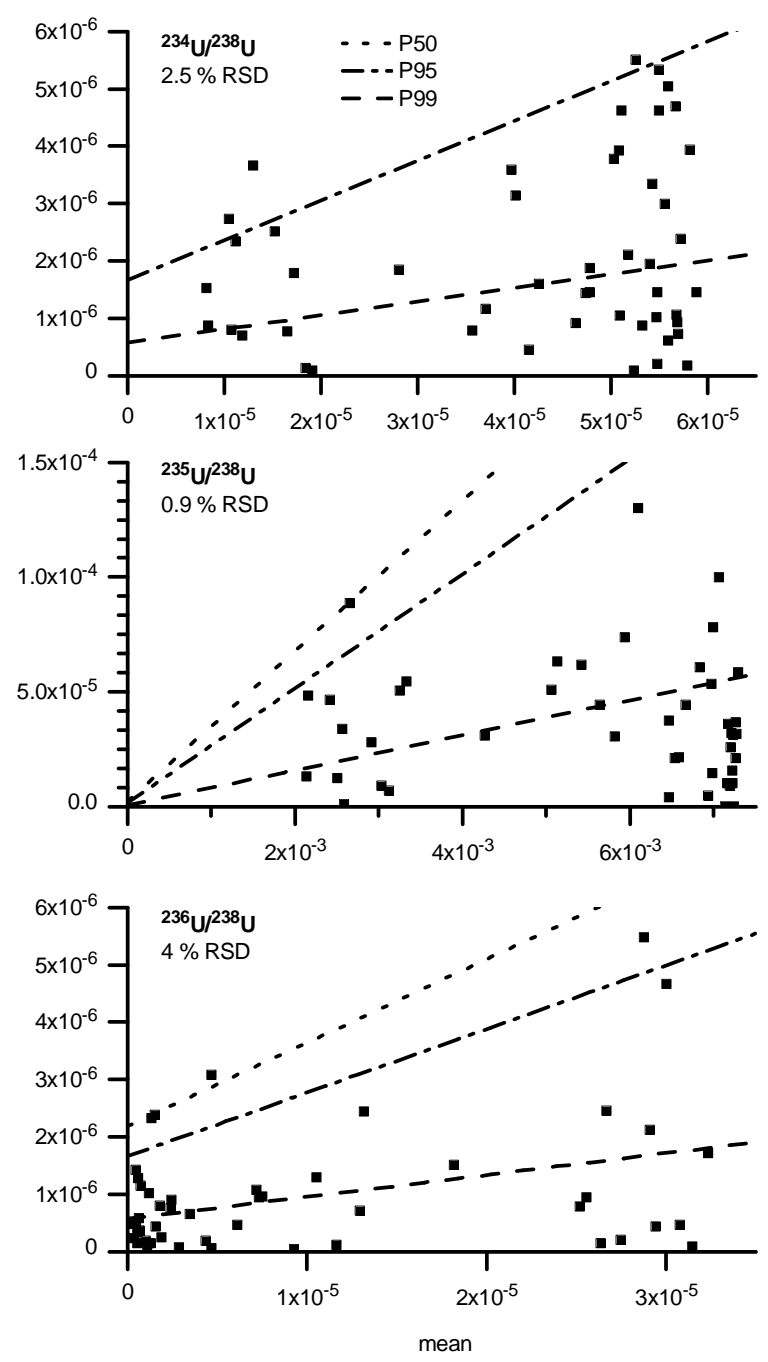

Figure 4. Thompson-Howarth duplicate control chart (amc 2002b) for uranium isotope ratios measured by ICP-QMS, used to assess analytical uncertainty $(k=1, n=49)$.

Table 2 summarises the results of multiple analyses of quality control solutions. Two are reported (marginally) outside of the reference values; these are for highly enriched uranium, exaggerating minor inaccuracy in the mass bias correction or detector linearity. The quality control solutions available for ${ }^{236} \mathrm{U} /{ }^{238} \mathrm{U}$ are not ideal for DU due to the relatively high abundance of ${ }^{236} \mathrm{U}$ and ${ }^{235} \mathrm{U}$. 


\begin{tabular}{|c|c|c|c|c|}
\hline QC Solution & $\mathbf{n}$ & ${ }^{234} \mathrm{U} /{ }^{238} \mathrm{U}\left(\mathrm{x} 10^{-5}\right)$ & ${ }^{235} \mathrm{U} /{ }^{238} \mathrm{U}\left(\times 10^{-3}\right)$ & ${ }^{236} U /{ }^{238} U\left(x 10^{-5}\right)$ \\
\hline $\begin{array}{l}\text { REIMEP 18-A } \\
\text { reference value* }\end{array}$ & 29 & $\begin{array}{l}5.66 \pm 0.05 \\
5.6582 \pm 0.0041\end{array}$ & $\begin{array}{l}7.257 \pm 0.008 \\
7.2542 \pm 0.0036\end{array}$ & $\begin{array}{l}<0.2 \\
0.0030579 \pm \\
0.0000083\end{array}$ \\
\hline $\begin{array}{l}\text { REIMEP 18-B } \\
\text { reference value* }\end{array}$ & 7 & $\begin{array}{l}33.1 \pm 0.5 \\
33.271 \pm 0.022\end{array}$ & $\begin{array}{l}35.3 \pm 0.1 \\
35.470 \pm 0.018\end{array}$ & $\begin{array}{l}38.5 \pm 0.8 \\
38.828 \pm 0.013\end{array}$ \\
\hline $\begin{array}{l}\text { REIMEP 18-C } \\
\text { reference value* }\end{array}$ & 38 & $\begin{array}{l}7.90 \pm 0.05 \\
7.9510 \pm 0.0068\end{array}$ & $\begin{array}{l}4.385 \pm 0.006 \\
4.3794 \pm 0.0027\end{array}$ & $\begin{array}{l}102.9 \pm 0.9 \\
103.370 \pm 0.044\end{array}$ \\
\hline $\begin{array}{l}\text { REIMEP 18-D } \\
\text { reference value* }\end{array}$ & 7 & $\begin{array}{l}21.0 \pm 0.3 \\
20.936 \pm 0.014\end{array}$ & $\begin{array}{l}24.11 \pm 0.08 \\
24.233 \pm 0.012\end{array}$ & $\begin{array}{l}<0.2 \\
0.011054 \pm 0.000029\end{array}$ \\
\hline $\begin{array}{l}\text { JR-2 (natural) } \\
\text { reference value }\end{array}$ & 28 & $\begin{array}{l}5.48 \pm 0.05 \\
5.486-5.49^{* *}\end{array}$ & $\begin{array}{l}7.26 \pm 0.01 \\
7.257 \pm 0.009\end{array}$ & $\begin{array}{l}<0.2 \\
<0.00001\end{array}$ \\
\hline $\begin{array}{l}\text { SDO-1 (natural) } \\
\text { reference value }\end{array}$ & 25 & $\begin{array}{l}5.49 \pm 0.05 \\
\text { presumed c. } 5.5\end{array}$ & $\begin{array}{l}7.26 \pm 0.01 \\
7.257 \pm 0.009\end{array}$ & $\begin{array}{l}<0.2 \\
<0.00001\end{array}$ \\
\hline $\begin{array}{l}\text { 'NSLDU'*** } \\
\text { MC-ICP-MS data }\end{array}$ & $\begin{array}{l}11 \\
1\end{array}$ & $\begin{array}{l}3.98 \pm 0.06 \\
3.9 \pm 0.1\end{array}$ & $\begin{array}{l}5.53 \pm 0.01 \\
5.54 \pm 0.02\end{array}$ & $\begin{array}{l}1.03 \pm 0.04 \\
0.9 \pm 0.1\end{array}$ \\
\hline
\end{tabular}

Table 2. Quality control data for 5 reference solutions, data reported as mean and standard error of the mean $(\mathrm{k}=2)$. The majority of the data are within uncertainty of reference values. * Richter et al. (2006); ${ }^{* *}$ GeoReM recommended value (Jochum et al. 2005); ${ }^{* * *}$ monitor solution from Colonie soil digest, compared with MC-ICP-MS analysis.

Twenty soil digests from across the isotope ratio range, were analysed by MC-ICP-MS (after uranium separation chemistry) for comparison with the ICP-QMS data. For ${ }^{235} \mathrm{U} /{ }^{238} \mathrm{U}$, all of the ICPQMS ratios were well within uncertainty of the MC-ICP-MS. MC-ICP-MS achieving c. 2.5 times higher measurement precision cf. ICP-QMS. For ${ }^{234} \mathrm{U} /{ }^{238} \mathrm{U}$, one in twenty was outside of uncertainty (appropriate for $95 \%$ confidence interval), also without systematic bias. Of the seven ${ }^{236} \mathrm{U} /{ }^{238} \mathrm{U}$ ratios quantified by ICP-QMS, there was a slight positive bias relative to the MC-ICP-MS data, but all were reported within uncertainty.

Slightly higher ${ }^{235} \mathrm{U} /{ }^{238} \mathrm{U}$ precision (1\%) was reported by Zheng and Yamada (2006) after analyte separation chemistry. ${ }^{232} \mathrm{Th}^{1} \mathrm{H}_{2}$ interference on ${ }^{234} \mathrm{U} /{ }^{238} \mathrm{U}$ is highly unlikely to be an issue as ${ }^{235} \mathrm{U}^{1} \mathrm{H}$ was minimised by the desolvating nebuliser. There is no evidence of positive bias in ${ }^{235} \mathrm{U} /{ }^{238} \mathrm{U}$ from the organic rich SDO-1, or for unseparated solutions when compared to analyte-separated solutions. 
5. Results \& Discussion

\subsection{Isotope mixing Lines}

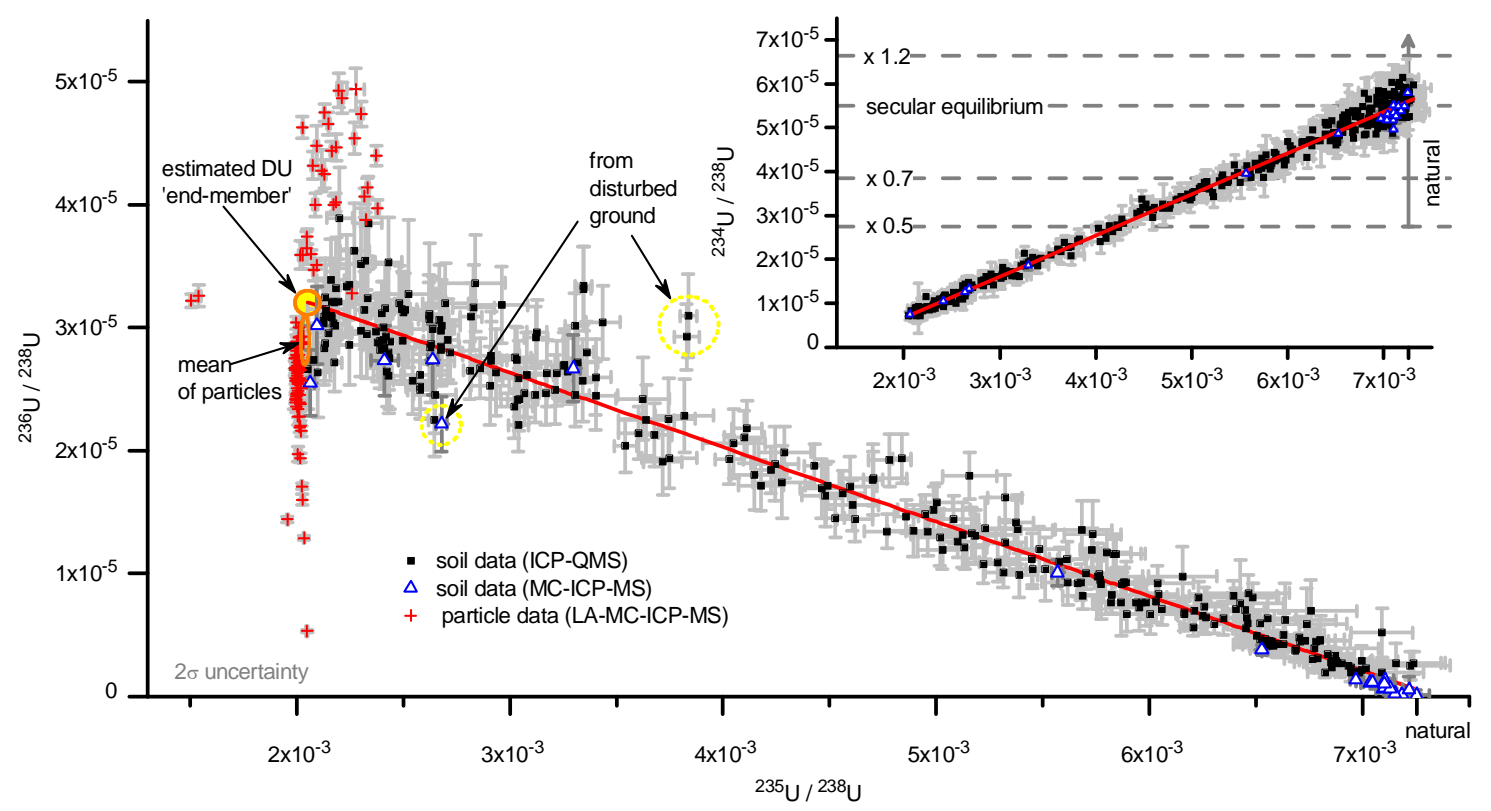

Figure 5. Plot of ${ }^{236} \mathrm{U} /{ }^{238} \mathrm{U}$ against ${ }^{235} \mathrm{U} /{ }^{238} \mathrm{U}$, defining a mixing line between $\mathrm{NU}$ and a DU end-member (weighted, adj. $\mathrm{R}^{2}$ 0.97). At least some of the scatter can be accounted for by the heterogeneity of the particulate (data plotted from Chapter 5 / Lloyd et al. 2009c). The 'average end-member' DU composition is estimated $(2.05 \pm 0.06) \times 10^{-3}{ }^{235} \mathrm{U} /{ }^{238} \mathrm{U},(3.2 \pm 0.1) \times 10^{-5}{ }^{236} \mathrm{U} /{ }^{238} \mathrm{U}(\mathrm{n}=405)$. The ICP-QMS data are in agreement with the MC-ICP-MS. Two samples are highlighted as examples of scatter from the mixing line, which are discussed further in the text.

Figure 5 Inset. Plot of ${ }^{234} \mathrm{U} /{ }^{238} \mathrm{U}$ against ${ }^{235} \mathrm{U} /{ }^{238} \mathrm{U}$; there is less scatter on this mixing line (weighted, adj. $\left.R^{2} 0.99\right)$. DU end-member estimated as $(7.1 \pm 0.3)$ $\times 10^{-6}{ }^{234} \mathrm{U} /{ }^{238} \mathrm{U}$; NU $(5.60 \pm 0.06) \times 10^{-5}$. Lines mark secular equilibrium, the typical range of natural fractionation in soils, $0.7-1.2$ (Szabo \& Rosholt 1982), and 0.5 recorded for a natural geological sample (Fleischer 2008).

Figure 5 shows mixing lines between an average DU composition and natural uranium, there is no evidence for mixing with enriched uranium (which was also handled by NLI). The isotopic compositions of the particulate contamination are heterogeneous, which is reflected in the scatter of the bulk sample data from the mixing line (supported by MC-ICP-MS analyses).

The upper highlighted (duplicate) sample data deviate significantly from the line, requiring a high degree of 'selectivity' from the high ${ }^{236} \mathrm{U}$ particle population. It is unlikely that this is from nugget effect. The location is on a small terrace of the stream that flows from the NLI site, and adjacent to an old rubbish tip on land cleared during the 1960's. It is possible that related ground disturbance have masked earlier contamination, or that NLI liquid discharges were isotopically 
distinct. The lower ${ }^{236} \mathrm{U}$ data highlighted is also from disturbed ground, a filled depression that may have received NLI wastes.

The lowest measured ${ }^{235} \mathrm{U} /{ }^{238} \mathrm{U}$ ratio from a bulk sample was $(2.06 \pm 0.02) \times 10^{-3}$, with a uranium concentration of $220 \pm 19 \mu \mathrm{g} \mathrm{g}^{-1}$. From this concentration, the sample probably comprises greater than $99 \%$ DU of total uranium. The DU 'end-member' cannot be known precisely, and the particle data from Lloyd et al. (Chapter 5 / 2009c) show there were a variety of DU isotopic compositions used at NLI. The mean isotopic compositions of the particle data are $(2.04 \pm 0.02) \times 10^{-3}$ for ${ }^{235} \mathrm{U} /{ }^{238} \mathrm{U}$, and $(2.9$ $\pm 0.2) \times 10^{-5}$ for ${ }^{236} \mathrm{U} /{ }^{238} \mathrm{U}$, but these data may not be fully representative. For a ${ }^{235} \mathrm{U} /{ }^{238} \mathrm{U}$ ratio of $\mathrm{c}$. $(2.05 \pm 0.06) \times 10^{-3}$, from a linear functional relationship of maximum likelihood (amc 2002a), the ${ }^{236} \mathrm{U} /{ }^{238} \mathrm{U}$ ratio is $(3.2 \pm 0.1) \times 10^{-5}$. The 'average end-member' is similar to the mean of the particle data.

The inset graph of ${ }^{234} \mathrm{U} /{ }^{238} \mathrm{U}$ against ${ }^{235} \mathrm{U} /{ }^{238} \mathrm{U}$ shows a well-defined mixing line between natural uranium and a depleted uranium end-member. There is less deviation from this mixing line, compared to ${ }^{236} \mathrm{U} /{ }^{238} \mathrm{U}$ against ${ }^{235} \mathrm{U} /{ }^{238} \mathrm{U} \cdot{ }^{234} \mathrm{U} /{ }^{238} \mathrm{U}$ depletion is approximately equal to ${ }^{235} \mathrm{U} /{ }^{238} \mathrm{U}$ depletion in an enrichment cascade, whereas ${ }^{236} \mathrm{U}$ is from the introduction of variable quantities of reprocessed reactor tails to the cascade (Smith 1984). The estimated end-members comprise $(5.60 \pm 0.05) \times 10^{-5}{ }^{234} \mathrm{U} /{ }^{238} \mathrm{U}$ for natural uranium and $(7.1 \pm 0.3) \times 10^{-6}$ for depleted uranium. Eighteen uranium oxide particles from Colonie have been individually analysed by MC-ICP-MS, with a mean ${ }^{234} \mathrm{U}^{238} \mathrm{U}$ ratio of $(7.3 \pm 0.1)$ $\mathrm{x} 10^{-6}$, which is in close agreement with the present estimate (Chapter $6 /$ Lloyd et al. unpublished).

There is some evidence of increased scatter with respect to ${ }^{234} \mathrm{U} /{ }^{238} \mathrm{U}$ at the natural uranium end, c. $\pm 0.3 \times 10^{-5}$. The secular equilibrium of ${ }^{234} \mathrm{U} /{ }^{238} \mathrm{U}$ is $(5.50 \pm 0.02) \times 10^{-5}$ (Richter et al. 1999), but natural isotopic fractionation can vary this value by at least $0.5-14$ times, therefore ${ }^{234} \mathrm{U}$ is not a reliable indicator of anthropogenic contamination (Fleischer 2008). A 'typical' range for natural soils is given in (Szabo and Rosholt (1982), of $0.7-1.2$. Therefore, isolated ${ }^{234} U /{ }^{238} \mathrm{U}$ measurements of environmental samples with less than $58 \%$ DU contamination of total $\mathrm{U}$ cannot be resolved from natural. 


\subsection{Estimation of background uranium concentration}

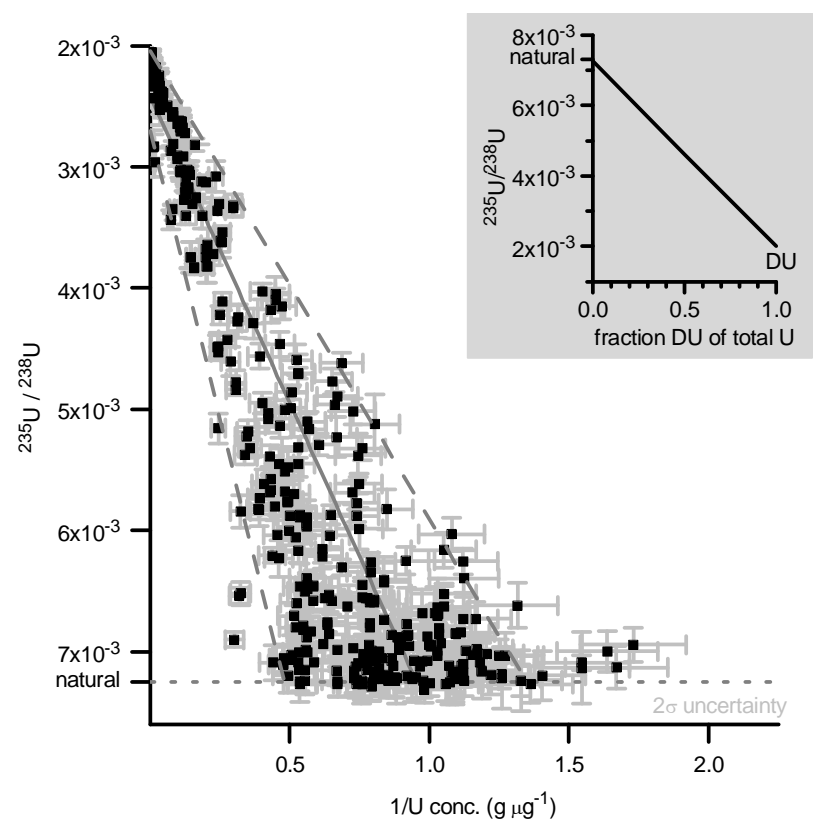

Figure 6. Plot of ${ }^{235} \mathrm{U} /{ }^{238} \mathrm{U}$ against 1/uranium concentration (all soils samples), which allows the natural background concentration range to be estimated for Colonie soils: weighted geometric mean $1.05 \pm 0.06 \mathrm{mg} \mathrm{g}^{-1}$; range $0.7-2.1 \mu \mathrm{g} \mathrm{g}^{-1}(\mathrm{n}=356)$. Inset plot of ${ }^{235} \mathrm{U} /{ }^{238} \mathrm{U}$ against the fraction $\mathrm{DU}$ of total $\mathrm{U}$ (after Bleise et al. 2003).

From the uranium concentration and isotope ratio data from the analysed samples, it is possible to estimate the range of natural uranium in the Colonie soils. Figure 6 shows that the concentration data spread out as the isotopic composition of natural uranium is approached. The concentration range for natural uranium can be estimated: $0.7-2.1 \mu \mathrm{g} \mathrm{g}{ }^{-1}$ with a weighted geometric mean of $1.05 \pm 0.06$ $\mu \mathrm{g} \mathrm{g}^{-1}$. This is significantly lower than $6 \mu \mathrm{g} \mathrm{g}^{-1}$ estimated for this area by Jeter and Eagleson (1980), but slightly higher than the mean sediment concentration of $0.6 \mu \mathrm{g} \mathrm{g}^{-1}$ for this area (USGS 2004). 


\subsection{Depth profiles}
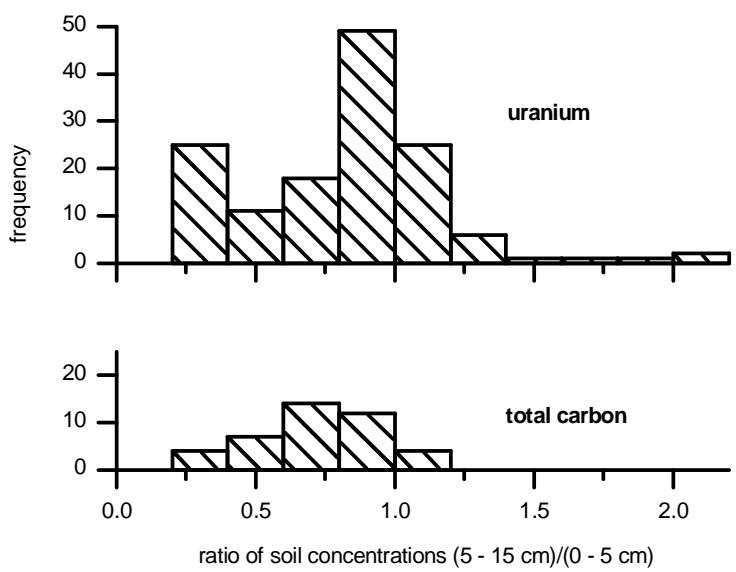

Figure 7. Histogram of the ratios of soil concentrations from two depth intervals, $5-15$ and $0-5 \mathrm{~cm}$ from surface. Uranium concentration typically decreases from surface (median ratio 0.9 ). Total carbon ( $\approx$ organic carbon) also decreases from surface (median ratio 0.7 ).

Figure 7 shows that there is typically a decrease in uranium concentration from the surface $0-5$ $\mathrm{cm}$ interval to the $5-15 \mathrm{~cm}$. There is also a decrease in total carbon from surface. These trends are explored in the following depth profiles.

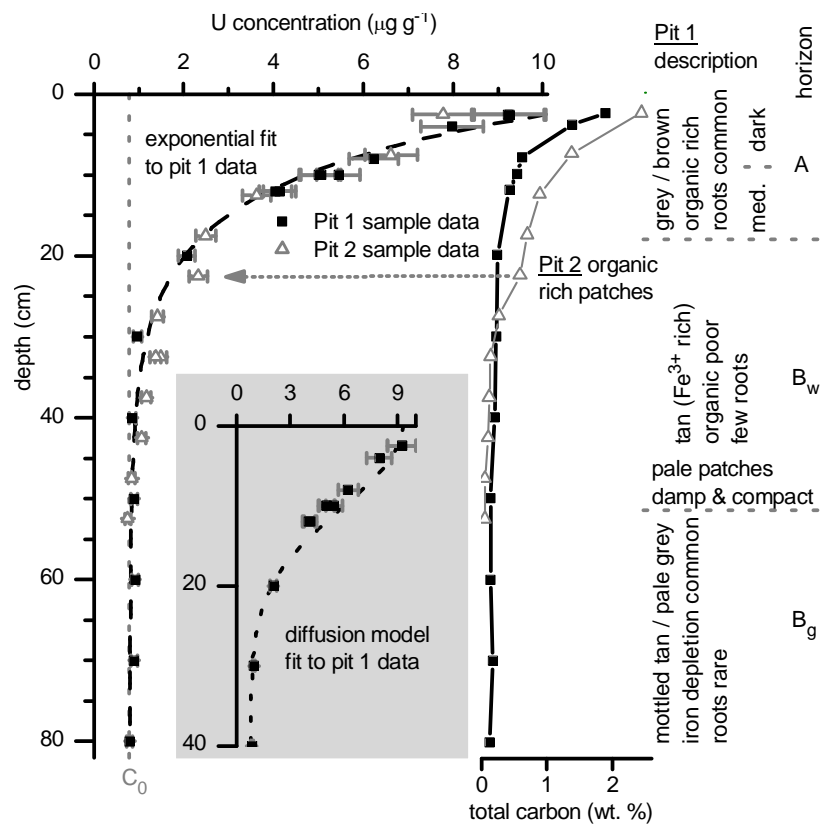

Figure 8 (left). Uranium concentration against depth, showing similar trends from two adjacent sampling pits. An exponential line provides a good (weighted) fit to the concentration data from pit 1 (concentration $=0.8+12.4 \mathrm{x}$ $\mathrm{e}^{-0.116 \times \text { depth }}$, adj. $R^{2}$ 0.97). Inset, a simplistic diffusion model with coefficient (D) of $1.4 \mathrm{~cm}^{2} \mathrm{a}^{-1}$ approximates the pit 1 data. 
Figure 8 (right). Total carbon (symbol size $\approx$ uncertainty) also follows an exponential trend, decreasing with depth. Soil horizon description for pit 1 ; Stafford Series, somewhat poorly drained loamy fine sands, with negligible calcium carbonate content (USDA 2006). The water table was c. $1 \mathrm{~m}$ below surface in July and the mean soil pH was 4.8 .

The concentrations from two depth profiles (c. 0.52 and $0.57 \mathrm{~km} \mathrm{~N}$ of NLI) are plotted in Figure 8. The two profiles follow a similar trend, and show an exponential decrease in concentration from surface, levelling off to a background concentration of c. $0.8 \mu \mathrm{g} \mathrm{g}^{-1}$ beyond approximately $40 \mathrm{~cm}$ depth. Contamination decreases exponentially with depth in each of seven profiles, from pits of varying distance and direction from NLI, which are plotted for ${ }^{235} \mathrm{U} /{ }^{238} \mathrm{U}$ in Figure 9.

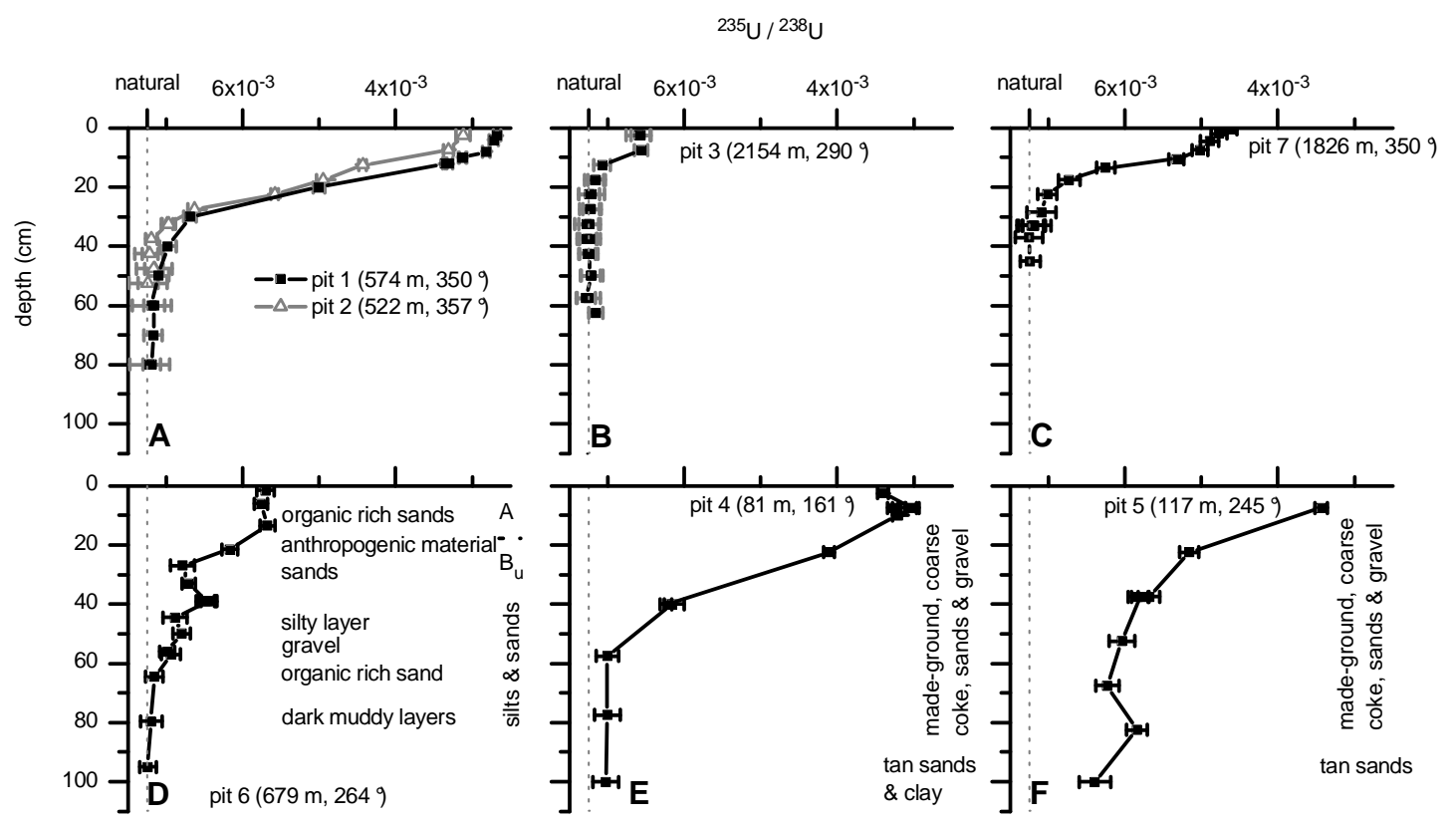

Figure 9. Uranium isotope ratios with respect to soil depth, showing exponential increase from depleted values near surface to natural at depth, i.e. decrease in DU contamination. The dotted line is the natural isotopic composition. Labels state distance and bearing of sampling location from NLI.

Profiles in A - C are from woodland locations, with loamy fine sands similar to those previously described. The profile in $D$ appears have been disturbed (proximal to 190); there is an apparent accumulation of DU contamination above a silty layer at $41 \mathrm{~cm}$ depth, beneath this fluvial sediments. E \& F are from madeground (sampled by hand auger, cross-contamination may account for the bump in F): the surface $90 \mathrm{~cm}$ comprises coke, sand and clay, beneath this are sands \pm clay; contamination persists to depths greater than $1.1 \mathrm{~m}$.

Integration of the fitted exponential curve can be used to estimate the total deposition at this location, approximately $0.9 \pm 0.2 \mathrm{~g} \mathrm{~m}^{-2}$. It is estimated that presently c. $45 \%$ of the contamination is within the surface $5.1 \mathrm{~cm}$ (1979 survey interval), $82 \%$ within the surface $15 \mathrm{~cm}$ (this study), and $99 \%$ within $40 \mathrm{~cm}$. It is therefore probable that the total mass of depleted uranium contamination was underestimated. However, the vertical distribution of contamination has probably changed since 1979. 
Short-term soil mixing is discussed in Kaste et al. (2007), and dispersion of contaminants can be modelled by combinations of advection and diffusion and/or decomposition of the organic horizon. The advection term is from the downward flux of water through the soil surface, entraining dissolved, complexed and colloidal bound contaminant. An advection model would feature a pulse that had migrated downward from surface. Diffusion transport appears to control the observed uranium concentration depth profiles.

Bioturbation by deep burrowing (anecic) earthworms can be a significant mechanism for vertical transport of low-solubility and strongly sorbing contamination (Müller-Lemans \& Van Dorp 1996), vertical burrows were observed in some of these soil profiles (Figure 4, Appendix 3). Earthworms are also known to be tolerant of heavy metal contamination (e.g. Sizmur \& Hodson 2009), with a predicted no-effect concentration of at least $100 \mu \mathrm{g} \mathrm{g}^{-1}$ for uranium (Sheppard et al. 2005).

Total carbon also decreases exponentially from surface, note the slight bump for pit 2 at $20-25$ $\mathrm{cm}$ where organic rich patches were observed (heterogeneity); there is also a bump in the uranium curve. Oliver et al. (2008) observed similar trends for uranium and loss on ignition from firing range soils, but concluded that there was no significance for a direct relationship from their data. Differences in these exponential rates could be accounted for by the decomposition of organic material. It is possible that particulate is being physically mixed with organic carbon, or that dissolved uranium species are binding with the organic carbon.

Within the $\mathrm{pH}$ range of Colonie soils, in oxidising near-surface waters, either solid schoepite (hydrated uranyl oxy-hydroxide) or dissolved uranyl $\left(\mathrm{UO}_{2}{ }^{2+}{ }_{(\mathrm{aq})}\right)$ are likely to be thermodynamically stable (Langmuir 1997). However, the Colonie soils are generally well-drained, and at least for oxidation in air, kinetics and surface passivation may limit bulk oxidation beyond $\mathrm{UO}_{2+\mathrm{x}}(\mathrm{s})$ (McEachern \& Taylor 1998), as appears to be the case for a few primary particles recovered from Colonie soils (Chapter 3 / Lloyd et al. 2009b). Schoepite has a solubility three orders of magnitude greater than $\mathrm{UO}_{2+\mathrm{x}}$ (Ragnarsdottir \& Charlet 2000), therefore speciation is significant for contaminant transport and bioaccessibility.

The majority of uranyl ions from the oxidative dissolution of $\mathrm{UO}_{2}$ will strongly adsorb to ferric oxyhydroxides and organic matter in soils (Langmuir 1997); uranyl ions are rapidly removed from solution by association with organic matter (Dong et al. 2006). Sequential extraction of firing range soils shows an association of DU with the oxidisable 'organic' fraction (Oliver et al. 2008). However, it is not clear from the literature which extraction step would leach uranium oxide particulates or other uranium species. For both primary particulate (observed) and adsorbed uranyl species (expected), the contamination is likely to be dispersed by physical mixing.

The source term for the Colonie contamination is emissions of uranium oxide particulate into the atmosphere, settling by wet and dry deposition onto the soil surface from 1958 - 1984: a broad pulse input of slightly shorter duration than has occurred since emissions ceased (emissions records are not available). Most of the NLI feedstock appears to have been sourced from Paducah gaseous diffusion plant tails from 1967 - 1969 (Chapter 6 / Lloyd et al. unpublished), and most of the contamination from NLI appears to be from prior to 1979. Therefore, the period of significant input can be narrowed to $1967-1979$.

A crude approximation of the source term is an instantaneous plane of DU on the soil surface 35 years before sampling. Contaminant concentration can then be modelled as a function of depth and time using the following diffusion equation from Crank (1975). 


$$
\mathrm{C}=\frac{\mathrm{M}}{\sqrt{\pi \mathrm{Dt}}} \mathrm{e}^{-\frac{\mathrm{z}^{2}}{4 \mathrm{Dt}}}
$$

Where $\mathbf{C}$ is the concentration of contaminant as a function of $\mathbf{z}$, soil depth $(\mathrm{cm})$, and $\mathbf{t}$, time (years, a), $\mathbf{M}$ is the total mass of contaminant $(\mu \mathrm{g})$ estimated by integrating the present concentration profile. The coefficient of diffusion, $\mathbf{D}\left(\mathrm{cm}^{2} \mathrm{a}^{-1}\right)$ can be estimated by least squares fitting to the sample data.

For pit 1, a diffusion coefficient (D) of c. $1.4 \mathrm{~cm}^{2} \mathrm{a}^{-1}$ is estimated, and if maintained, the surface soil concentration will halve in approximately 125 years time (pedological half-life). The estimate for the adjacent pit, pit 2, is $2.1 \mathrm{~cm}^{2} \mathrm{a}^{-1}$, giving a sense of the uncertainty involved. For a distant pit, pit 7 , with approximately $0.07 \pm 0.05 \mathrm{~g} \mathrm{~m}^{-2}$ total contamination $(\mathrm{M}), 1.4 \mathrm{~cm}^{2} \mathrm{a}^{-1}$ was estimated. From these models, the proportion of contamination beneath $5.1 \mathrm{~cm}$ in 1979 was approximately one third $(27-38$ $\%$ ), so it is likely that total contamination was c. $50 \%$ greater than previously estimated, i.e. c. 4.8 tonnes ${ }^{2}$. This simplified model does not reflect deposition of contamination on these soils over a period.

The diffusion coefficients are of a similar magnitude to that measured using ${ }^{210} \mathrm{~Pb}$ for a bioturbated temperate mineral soil by Kaste et al. (2007). A similar approach could help refine the model of the Colonie contamination. They are also within the range reported by Bunzl (2002) and Schuller et al. (1997). The mixing time derived for the A horizon of pit 1 is approximately 222 years, equating to a mass turnover of c. $0.6 \mathrm{~kg} \mathrm{~m}^{2} \mathrm{a}^{-1}$, compatible with earthworm bioturbation rates from temperate grasslands (summarised data in Bunnenberg \& Taeschner 2000). Physical mixing by earthworms (bioturbation) can account for the redistribution of contamination and organic carbon within the A horizon, and the contaminant appears to have very limited mobility. It is likely that bioturbation by earthworms is dispersing contaminant from the soil surface, in the form of primary uranium oxide particulates and uranyl species that are adsorbed to organic matter.

Profiles E \& F (Figure 9) are from made-ground situated between NLI and the railway. In 2006, these coarse, friable, coke-rich 'soils' (c. 25 - 50 wt. \% loss on ignition) comprised uranium up to 500 $\pm 40 \mu \mathrm{g} \mathrm{g}^{-1}$ (for Pb $1180 \pm 142, \mathrm{Cu} 1386 \pm 166$, Sn $279 \pm 34, \mathrm{Sb} 27 \pm 3 \mu \mathrm{g} \mathrm{g}^{-1}$ ). Subsequently this area was remediated by replacing some of the surface material with clean fill. These profiles were sampled by hand auger in 2007 (pit sampling was not possible). The top of profile E reflects replacement of the surface with cleaner material. Profiles E \& F show an exponential increase in ${ }^{235} \mathrm{U} /{ }^{238} \mathrm{U}$, but they do not reach natural composition within the surface $1.1 \mathrm{~m}$.

\subsection{Uranium contamination map (concentration)}

The concentration data from shallow soils are plotted and interpolated in Figure 10. Uranium concentrations greater than $12 \mu \mathrm{g} \mathrm{g}^{-1}$ were excluded from the interpolation, because these heavily skew the dataset. The excluded data were mostly within $200 \mathrm{~m}$ of NLI and access to undisturbed sites within the north of this area was difficult. This dataset does not significantly increase the estimate of total uranium emissions, which are concentrated within the area of the 1979 survey. Significantly elevated concentrations $\left(3.4 \pm 0.3 \mu \mathrm{g} \mathrm{g}^{-1}\right)$ are measured up to $1.9 \mathrm{~km} \mathrm{NNW}$ of NLI, likely to comprise $31-81$ $\%$ contamination of total uranium.

The concentration of ${ }^{238} \mathrm{U}$ (converted from activity) for surface soils on the railroad south of NLI in 1968 were reported as $163 \mu \mathrm{g} \mathrm{g}^{-1}$ (NYSDOH 1979), in 1979 up to $3080 \pm 65$ (Jeter \& Eagleson

${ }^{2}$ The uncertainty on this figure was estimated to be in the order of \pm 1 tonne. 
1980). The representativity and comparability of the earlier measurement is not clear, but it suggests that the majority of the contaminant uranium probably occurred during 1968-1979. Proximal locations, within $30 \mathrm{~m}$ of each other, comprised $458 \pm 16 \mu \mathrm{g} \mathrm{g}^{-1}$ in $1979,500 \pm 40 \mu \mathrm{g} \mathrm{g}^{-1}$ in 2006 , and then after environmental remediation in $2007,7.9 \pm 0.6 \mu \mathrm{g} \mathrm{g}^{-1}$.

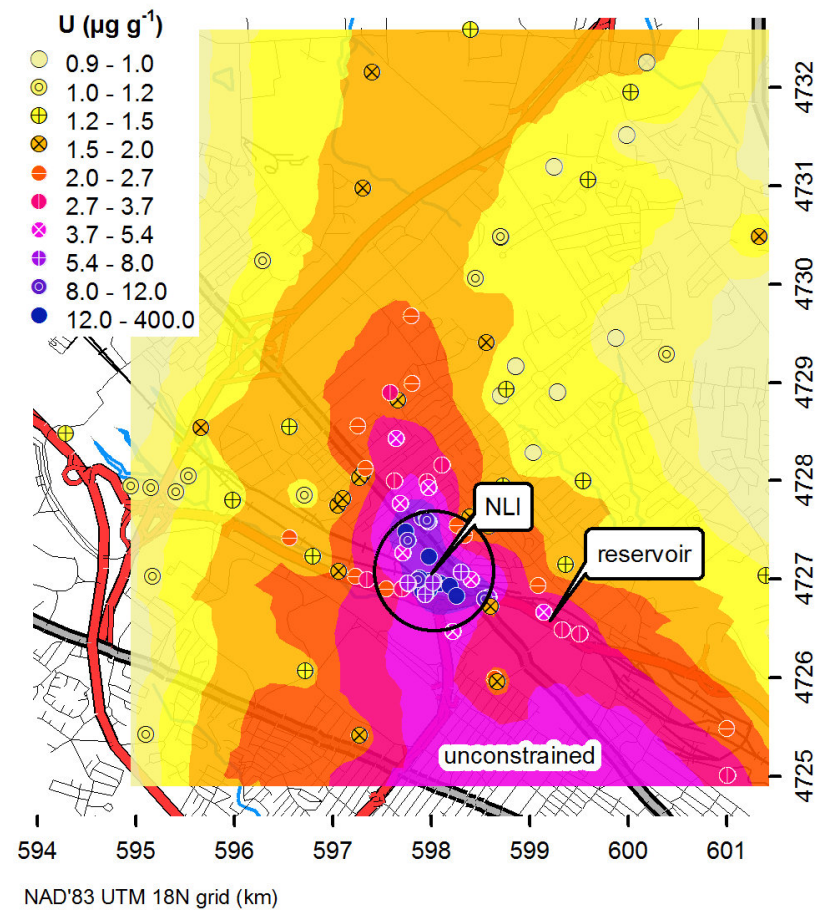

Figure 10. Map of uranium concentration in surface soils $(0-5 \mathrm{~cm})$, ordinary kriging excluding data greater than $12 \mathrm{\mu g} \mathrm{g}^{-1}$ (log transform, quadratic trend removal, exponential semivariogram model; cross-validation statistics: mean standardised error $0.03, \mathrm{RM}^{2}$ standardised error 0.97 ). The southern extent is poorly constrained, due to difficulty accessing undisturbed sites in this more densely populated neighbourhood; Figure 2 (1979 survey extent circled) suggests that the southward distribution is much less extensive than shown here. A sediment core from the labelled reservoir was previously analysed by Arnason and Fletcher (2003).

A sediment core from the Patroon reservoir (labelled) was sampled and analysed by Arnason and Fletcher (2003), with mean and maximum uranium concentrations of 13 and $320 \mu \mathrm{g} \mathrm{g}^{-1}$. In contrast, the surface soil concentration interpolated for this location is $3.6 \pm 2.9 \mu \mathrm{g} \mathrm{g}^{-1}$. This clearly shows that uranium accumulated in the reservoir sediment, either from runoff from the Patroon creek watershed, or from direct discharges from the NLI site into the Patroon Creek (approximately $1.6 \mathrm{~km}$ upstream). Some of the reservoir sediment contaminant appears to be from U(VI) species (Arnason et al. 2008), implying at least some dissolution and reprecipitation. 


\subsection{DU contamination map (isotope ratio)}

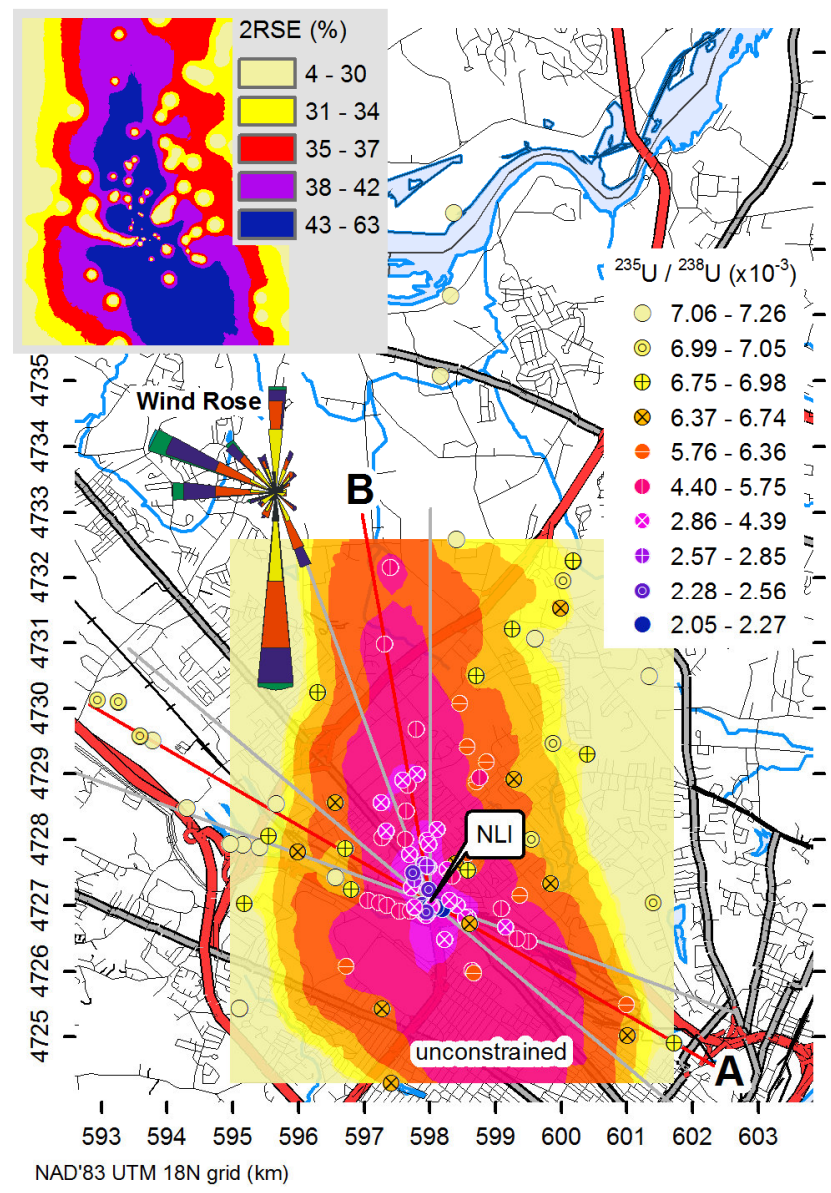

Figure 11. Map showing the distribution of DU contamination in surface soils $(0-5 \mathrm{~cm})$ using ordinary kriging (quadratic trend removal, exponential semivariogram model; cross validation statistics: mean standardised error $0.0073, \mathrm{RM}^{2}$ standardised error 0.95 , relative standard error map inset). The southern extent is poorly constrained, due to difficulty accessing undisturbed sites in this densely populated neighbourhood; Figure 2 suggests that the southward distribution is much less extensive than shown here. DU has been detected in soils at least $5.1 \mathrm{~km}$ NNW of NLI (DU detection limit c. $7.06 \times 10^{-3}$ ${ }^{235} \mathrm{U} /{ }^{238} \mathrm{U}$ ). Wind rose from Figure 2, approximate weather station location. Transect lines marked A and B are referred to in Figure 12.

A map of ${ }^{235} \mathrm{U} /{ }^{238} \mathrm{U}$ is presented in Figure 11, which reveals the extent of DU contamination. The previously discussed surface sample, $1.9 \mathrm{~km} \mathrm{NNW}$ of NLI comprises $(3.34 \pm 0.06) \times 10^{-3}$ ${ }^{235} \mathrm{U} /{ }^{238} \mathrm{U}, 73-76 \%$ DU of total $\mathrm{U}$ (see Figure 6 inset). More than one third of the total uranium in a surface soil sample from $5.1 \mathrm{~km}$ NNW of NLI is depleted uranium contamination. These maps demonstrate the sensitivity and potential precision of ${ }^{235} \mathrm{U} /{ }^{238} \mathrm{U}$ for defining the contamination footprint. This approach could be used to assess the historic exposure potential of residents, a prerequisite for a proposed health study in the Colonie area. Exposure of a sub-group could be verified using urine analyses (Parrish et al. 2008). 


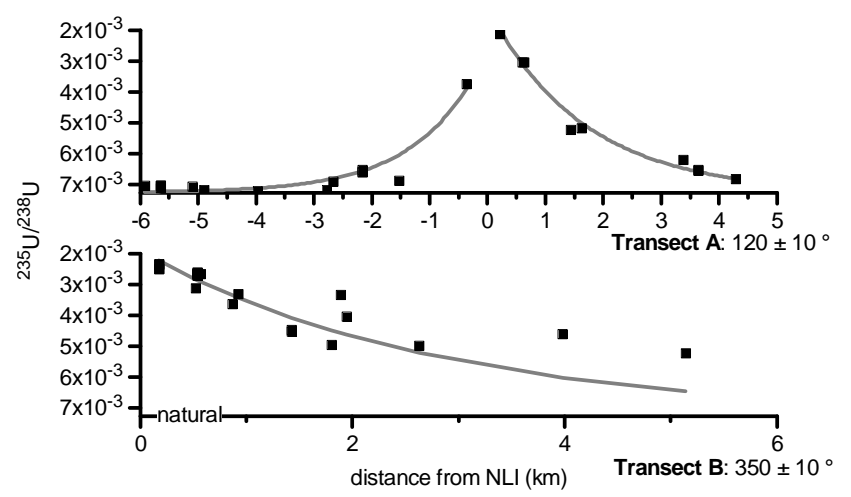

Figure 12. Profiles drawn along transects $A$ and $B$ (marked on Figure 11), from measured data (symbol height $\approx$ uncertainty), showing an exponential increase in ${ }^{235} \mathrm{U} /{ }^{238} \mathrm{U}$ towards natural with increasing distance from $\mathrm{NLI}$. Equations: Transect $A(N W) y=7.253 \times 10^{-3}-4.6 \times 10^{-3} e^{-0.0009 x}$, adj. $R^{2} \quad 0.90$; Transect A (SE) $y=7.253 \times 10^{-3}-6.0 \times 10^{-3} e^{-0.0006 x}$, adj. $R^{2} 0.99$; Transect B: $y=$ $7.253 \times 10^{-3}-5.3 \times 10^{-3} \mathrm{e}^{-0.0003 x}$, adj. $R^{2} 0.75$. Differences in the exponential rates can be attributed to wind speed frequency distributions for each direction (see Figure 11 for wind rose).

Figure 12 plots sample data from two transects crossing NLI (as marked on Figure 11). Transect $\mathrm{B}$ roughly follows the primary axis of deposition, transect $\mathrm{A}$ is at a divergent angle to this. The isotope ratios increase towards natural with distance from NLI, following exponential trends. This is typical of point-source atmospheric pollutant dispersal (e.g. De Caritat et al. 1997). The differences in exponential rate can be attributed to differences in wind speed frequency distributions for each direction; winds blowing towards $350 \pm 5^{\circ}$ occurred $6.4 \%$ of the time, towards $120 \pm 5^{\circ}$ for $4.5 \%$ of the time, $300 \pm 5^{\circ}$ for $5.1 \%$ but at lower speeds.

The typical detection limit for DU of $7.06 \times 10^{-3}{ }^{235} \mathrm{U}^{238} \mathrm{U}$ is equivalent to $4 \%$ DU of total $\mathrm{U}$, $0.05 \mu \mathrm{g} \mathrm{g}^{-1}$ DU with $1 \mu \mathrm{g} \mathrm{g}^{-1} \mathrm{NU}$, or one $84 \mu \mathrm{m}$ diameter DU dioxide particle in a $60 \mathrm{~g}$ aliquot of typical Colonie soil. Therefore, there could be potential for nugget effect during sub-sampling prior to milling. However, the aerodynamic diameter of such a particle is large, and dry deposition is likely within $100 \mathrm{~m}$ of NLI (if initially convected to $20 \mathrm{~m}$ above surface and transported by a high wind at 11 $\mathrm{m} \mathrm{s}^{-1}$ ) where surface soil DU concentrations are much higher.

DU contamination has been detected to at least $5.6 \mathrm{~km}$ WNW of NLI (against prevailing wind), $(7.03 \pm 0.04) \times 10^{-3}{ }^{235} \mathrm{U} /{ }^{238} \mathrm{U}(\mathrm{n}=4)$. Approximately $42 \mathrm{ng}$ of DU contaminates each gram of soil, equivalent to approximately $45 \mathrm{DU}$ dioxide particles of $6 \mu \mathrm{m}$ diameter (plausible for air transport at a more usual $3 \mathrm{~m} \mathrm{~s}^{-1}$ ) are required to 'contaminate' each gram of sample. Winds favourable for transport to that location were rare, occurring only $0.5 \%$ of the time. This area of the Pine Bush Preserve had recently been affected by a fire, and it is possible that this concentrated contamination from the combusted vegetation onto the soil surface.

\section{Conclusions}

The Colonie case-study has been suggested as a reasonable analogue for battlefield contamination by depleted uranium. In this paper, uranium isotope ratios measured by ICP-QMS have revealed the extent and spatial distribution of DU contamination surrounding the former NLI site. The mass of DU contamination surrounding NLI, within the surface $5.1 \mathrm{~cm}$ soils in 1979 was 
approximately 3.2 tonnes, but the total may be closer to 4.8 tonnes. This is significant within the context of emissions from battlefield deployment of DU munitions.

The quality control data show that accurate isotope ratios can be reliably measured by ICPQMS without the need for costly separation chemistry. Multi-isotope ratio plots resolve heterogeneity of the DU compositions previously observed from individual particle analyses. There is no evidence of enriched uranium in the bulk soil samples.

DU contamination can be detected in surface soils to at least $5.6 \mathrm{~km}$ from the NLI site using ${ }^{235} \mathrm{U} /{ }^{238} \mathrm{U}$. With further sampling and analyses, the northward contamination plume could be mapped in detail using this method. This would be useful for constraining the historic exposure potential of residents for proposed health studies in the Colonie area.

Isotope ratio and concentration data allow the natural background range of uranium concentration in Colonie soils to be estimated, $0.7-2.1 \mu \mathrm{g} \mathrm{g}^{-1}$ with a weighted geometric mean of 1.05 $\pm 0.06 \mu \mathrm{g} \mathrm{g}^{-1}$. The areal distribution of contamination was clearly controlled by prevailing winds.

The vertical distribution of DU contamination is closely related to the carbon content in the surface soil horizon, and can be explained by diffusion-like physical mixing. It is likely that bioturbation by earthworms is dispersing this low mobility contaminant from the soil surface, in the form of primary uranium oxide particulates and uranyl species that are adsorbed to organic matter.

\section{Acknowledgments}

This study was sponsored by the British Geological Survey and the NERC Isotope Geosciences Laboratory (NIGL). Simon Chenery publishes with the permission of the director of the British Geological Survey.

The authors would like to thank Mark A. Allen, John G. Arnason, Neil Breward, Matt S. A. Horstwood, Sarah V. Lee, Nick G. Marsh, Vanessa Pashley and Barry G. Rawlins. We are also grateful for local knowledge and support from members of Concerned Citizens about National Lead, especially Sharron Herr.

In memoriam Professor Tim S. Brewer (University of Leicester) for his invaluable involvement at the start of this research.

Albany Pine Bush Preserve Commission 2005. The Albany Pine Bush. World Wide Web Address: http://www.albanypinebush.org/preserve_information/preserve.htm (28/03/2009).

amc 2002a. Fitting a linear functional relationship to data with error on both variables. Royal Society of Chemistry, London Report amc technical brief no. 10.

amc 2002b. A simple fitness-for-purpose control chart based on duplicate results obtained from routine test materials. Royal Society of Chemistry, London Report amc technical brief no. 9.

Arnason, J. G. \& Fletcher, B. A. 2003. A 40+ year record of $\mathrm{Cd}, \mathrm{Hg}, \mathrm{Pb}$, and $\mathrm{U}$ deposition in sediments of Patroon Reservoir, Albany County, NY, USA. Environmental Pollution, 123 (3), 383-391.

Arnason, J. G., Lloyd, N. S., Parrish, R. R., Tang, Y. \& Reeder, R. J. 2008. Oxidation of uranium oxide aerosol particles in the near-surface environment. Geochimica et Cosmochimica Acta, 72 (12), A33. 
ATSDR 2004. Health Consultation: Colonie Site. Agency for Toxic Substances and Disease Registry, Atlanta, USA.

Berkovits, D., Feldstein, H., Ghelberg, S., Hershkowitz, A., Navon, E. \& Paul, M. $2000 .{ }^{236}$ U in uranium minerals and standards. Nuclear Instruments \& Methods in Physics Research, Section B: Beam Interactions with Materials and Atoms, 172 (1-4), 372-376.

Bleise, A., Danesi, P. R. \& Burkart, W. 2003. Properties, use and health effects of depleted uranium (DU): a general overview. Journal of Environmental Radioactivity, 64 (2-3), 93-112.

Boulyga, S. F., Matusevich, J. L., Mironov, V. P., Kudrjashov, V. P., Halicz, L., Segal, I., McLean, J. A., Montaser, A. \& Becker, J. S. 2002. Determination of ${ }^{236} \mathrm{U} /{ }^{238} \mathrm{U}$ isotope ratio in contaminated environmental samples using different ICP-MS instruments. Journal of Analytical Atomic Spectrometry, 17 (8), 958-964.

Buck, B. J., Brock, A. L., Johnson, W. H. \& Ulery, A. L. 2004. Corrosion of depleted uranium in an arid environment: Soil-geomorphology, SEM/EDS, XRD, and electron microprobe analyses. Soil and Sediment Contamination, 13 (6), 545-561.

Buck, E. C., Brown, N. R. \& Dietz, N. L. 1996. Contaminant uranium phases and leaching at the Fernald site in Ohio. Environmental Science and Technology, 30 (1), 81-88.

Bunnenberg, C. \& Taeschner, M. 2000. Soil fauna transport versus radionuclide migration. Radiation Protection Dosimetry, 92 (1-3), 35-38.

Bunzl, K. 2002. Transport of fallout radiocesium in the soil by bioturbation: A random walk model and application to a forest soil with a high abundance of earthworms. Science of the Total Environment, 293 (1-3), 191-200.

Crank, J. 1975. The Mathematics of Diffusion, $2^{\text {nd }}$ ed. Clarendon Press, Oxford, UK.

De Caritat, P., Reimann, C., Chekushin, V., Bogatyrev, I., Niskavaara, H. \& Braun, J. 1997. Mass balance between emission and deposition of airborne contaminants. Environmental Science and Technology, 31 (10), 2966-2972.

De Laeter, J. R., Böhlke, J. K., De Bièvre, P., Hidaka, H., Peiser, H. S., Rosman, K. J. R. \& Taylor, P. D. P. 2003. Atomic weights of the elements: Review 2000 (IUPAC Technical Report). Pure and Applied Chemistry, 75 (6), 683-800.

Dietz, L. A. 1980. Investigation of Excess Alpha Activity Observed in Recent Air Filter Collections and Other Environmental Samples. Knolls Atomic Power Laboratory, General Electric Company, Schenectady, NY, USA Report CHEM-434-LAD.

Dlouhy, J. A. 2009. Tonko: Study NL site impact. Times Union, Albany, NY, USA, 13/03/2009.

Dong, W., Xie, G., Miller, T. R., Franklin, M. P., Oxenberg, T. P., Bouwer, E. J., Ball, W. P. \& Halden, R. U. 2006. Sorption and bioreduction of hexavalent uranium at a military facility by the Chesapeake Bay. Environmental Pollution, 142 (1), 132-142.

Dunning, D. 1996. Derivation of guidelines for uranium residual radioactive material in soil at the Colonie Site, Colonie, New York. Argonne National Lab., Argonne, IL, USA Report ANL/EAD/TM-57.

Ehrlich, S., Harlavan, Y., Bar-Matthews, M. \& Halicz, L. 2004. Lead and uranium isotopic behavior in diagenetic and epigenetic manganese nodules, Timna Basin, Israel, determined by MC-ICPMS. Applied Geochemistry, 19 (12), 1927-1936.

EPA 1983. Mercury Refining Inc., New York. Environmental Protection Agency (Region 2), Albany, NY (USA) Report NYD048148175.

Finch, R. J. \& Ewing, R. C. 1992. Corrosion of uraninite under oxidizing conditions. Journal of Nuclear Materials, 190, 133-156.

Fleischer, R. L. 2008. Difficulties in using ${ }^{234} U /^{238} \mathrm{U}$ ratios to detect enriched or depleted uranium. Health Physics, 94 (3), 292-293.

Fomina, M., Charnock, J. M., Hillier, S., Alvarez, R., Livens, F. \& Gadd, G. M. 2008. Role of fungi in the biogeochemical fate of depleted uranium. Current Biology, 18 (9),

Green, K. A. 2007. Digestion of solid materials by hot block mixed acid attack. British Geological Survey, Keyworth, UK Report AGN 2.2.2 v. 2.0.

Gwiazda, R. H., Smith, D., Squibb, K. \& McDiarmid, M. 2004. Detection of depleted uranium in urine of veterans from the 1991 Gulf War. Health Physics, 86 (1), 12-18. 
Handley-Sidhu, S., Worsfold, P. J., Boothman, C., Lloyd, J. R., Alvarez, R., Livens, F. R., Vaughan, D. J. \& Keith-Roach, M. J. 2009. Corrosion and fate of depleted uranium penetrators under progressively anaerobic conditions in estuarine sediment. Environmental Science and Technology, 43 (2), 350-355.

Horwitz, E. P., Dietz, M. L., Chiarizia, R., Diamond, H., Essling, A. M. \& Graczyk, D. 1992. Separation and preconcentration of uranium from acidic media by extraction chromatography. Analytica Chimica Acta, 266 (1), 25-37.

Jeter, H. W. \& Eagleson, D. M. 1980. A survey of uranium in soils surrounding the NL Bearings Plant. Teledyne Isotopes, Westwood, NJ, USA Report IWL-9488-461.

Jochum, K. P., Nohl, L., Herwig, K., Lammel, E., Toll, B. \& Hofmann, A. W. 2005. GeoReM: A new geochemical database for reference materials and isotopic standards. Geostandards and Geoanalytical Research, 29 (3), 333-338.

Johnston, K., Ver Hoef, J. M., Krivoruchko, K. \& Lucas, N. 2001. Using ArcGIS Geostatistical Analyst. ESRI, Redlands, CA, USA.

Kaste, J. M., Heimsath, A. M. \& Bostick, B. C. 2007. Short-term soil mixing quantified with fallout radionuclides. Geology, 35 (3), 243-246.

Krupka, K. M., Parkhurst, M. A., Gold, K., Arey, B. W., Jenson, E. D. \& Guilmette, R. A. 2009. Physicochemical characterization of Capstone depleted uranium aerosols III: morphologic and chemical oxide analyses. Health Physics, 96 (3), 276-291.

Lakes 2005. WRPLOT View 5.9.0. Lakes Environmental Software, Waterloo, Canada.

Langmuir, D. 1997. Aqueous Environmental Geochemistry. Prentice-Hall International, London.

Lariviere, D., Taylor, V. F., Evans, R. D. \& Cornett, R. J. 2006. Radionuclide determination in environmental samples by inductively coupled plasma mass spectrometry. Spectrochimica Acta - Part B Atomic Spectroscopy, 61 (8), 877-904.

Lind, O. C., Salbu, B., Skipperud, L., Janssens, K., Jaroszewicz, J. \& De Nolf, W. 2009. Solid state speciation and potential bioavailability of depleted uranium particles from Kosovo and Kuwait. Journal of Environmental Radioactivity, 100 (4), 301-307.

Lloyd, N. S., Chenery, S. R. N. \& Parrish, R. R. 2009a. The distribution of depleted uranium contamination in Colonie, NY, USA. Science of the Total Environment, 408 (2), 397-407.

Lloyd, N. S., Mosselmans, J. F. W., Parrish, R. R., Chenery, S. R., Hainsworth, S. V. \& Kemp, S. J. 2009b. The morphologies and compositions of depleted uranium particles from an environmental case-study. Mineralogical Magazine, 73 (3), 493-508.

Lloyd, N. S., Parrish, R. R., Horstwood, M. S. A. \& Chenery, S. R. N. 2009c. Precise and accurate isotopic analysis of microscopic uranium-oxide grains using LA-MC-ICP-MS. Journal of Analytical Atomic Spectrometry, 24 (6), 752-758.

Lloyd, N. S., Chenery, S. R., Parrish, R. R. \& Horstwood, M. S. A. unpublished. Comparison of uranium isotope ratios from Colonie particles with Paducah Gaseous Diffusion Plant tails assays.

Lo, D., Fleischer, R. L., Albert, E. A. \& Arnason, J. G. 2006. Location, identification, and size distribution of depleted uranium grains in reservoir sediments. Journal of Environmental Radioactivity, 89 (3), 240-248.

McEachern, P., Myers, W. G. \& White, F. A. 1971. Uranium concentrations in surface air at rural and urban localities within New York State. Environmental Science and Technology, 5 (8), 700703.

McEachern, R. J. \& Taylor, P. 1998. A review of the oxidation of uranium dioxide at temperatures below $400{ }^{\circ} \mathrm{C}$. Journal of Nuclear Materials, 254 (2-3), 87-121.

Müller-Lemans, H. \& Van Dorp, F. 1996. Bioturbation as a mechanism for radionuclide transport in soil: Relevance of earthworms. Journal of Environmental Radioactivity, 31 (1), 7-20.

NEA \& IAEA 2001. Management of depleted uranium. OECD Publications, Paris.

Neuilly, M., Bussac, J., Frèjacques, C., Nief, G., Vendryes, G. \& Yvon, J. 1972. Sur l'existence dans un passé reculeé d'une réaction en chaîne naturelle de fissions, dans le gisement d'uranium d'Oklo (Gabon). Comptes Rendus de l'Academie des Sciences, Paris, Serie D, 275 (17), 18471849 . 
NYS Geological Survey 1999. Hudson Mohawk Sheet. NYS Museum Technology Center, Albany, NY, USA.

NYSDOH 1979. DRAFT Status report - Environmental and public health evaluation of discharges National Lead Industries. N.Y.S. Department of Health.

Oliver, I. W., Graham, M. C., MacKenzie, A. B., Ellam, R. M. \& Farmer, J. G. 2008. Distribution and partitioning of depleted uranium (DU) in soils at weapons test ranges - Investigations combining the BCR extraction scheme and isotopic analysis. Chemosphere, 72 (6), 932-939.

Parkhurst, M. A., Daxon, E. G., Lodde, G. M., Szrom, F., Guilmette, R. A., Roszell, L. M., Falo, G. A. \& McKee, C. B. 2004. Capstone Aerosols: Depleted Uranium Aerosol Doses and Risks. Battelle for U.S. Army.

Parrish, R. R., Horstwood, M., Arnason, J. G., Chenery, S., Brewer, T., Lloyd, N. S. \& Carpenter, D. O. 2008. Depleted uranium contamination by inhalation exposure and its detection after 20 years: Implications for human health assessment. Science of the Total Environment, 390 (1), 58-68.

Peel, M. C., Finlayson, B. L. \& McMahon, T. A. 2007. Updated world map of the Köppen-Geiger climate classification. Hydrology and Earth System Sciences, 11 (5), 1633-1644.

Plant, J. A. \& Saunders, A. D. 1996. The radioactive earth. Radiation Protection Dosimetry, 68 (1-2), 25-36.

Priest, N. D. 2001. Toxicity of depleted uranium. Lancet, 357 (9252), 244-246.

Ragnarsdottir, K. V. \& Charlet, L. 2000. Uranium in Natural Environments. In: J. D. Cotter-Howells, L. S. Campbell, E. Valsami-Jones \& M. Batchelder (eds) Environmental Mineralogy: Microbial Interactions, Anthropogenic Influences, Contaminated Land and Waste Management. Mineralogical Society, London.245-289.

Rawlins, B. G., Lark, R. M., Webster, R. \& O'Donnell, K. E. 2006. The use of soil survey data to determine the magnitude and extent of historic metal deposition related to atmospheric smelter emissions across Humberside, UK. Environmental Pollution, 143 (3), 416-426.

Richter, S., Alonso, A., De Bolle, W., Wellum, R. \& Taylor, P. D. P. 1999. Isotopic 'fingerprints' for natural uranium ore samples. International Journal of Mass Spectrometry, 193 (1), 9-14.

Richter, S., Alonso, A., Truyens, J., Kühn, H., Verbruggen, A. \& Wellum, R. 2006. Certification Report: REIMEP 18 Inter-Laboratory Comparison for the Measurement of Uranium Isotopic Ratios in Nitric Acid Solution. Institute for Reference Materials and Measurements, Luxembourg Report EUR 22244 EN. Office for Official Publications of the European Communities.

Romano, D. J. 1982. Comments to assembly committee on environmental conservation hearing concerning uranium waste disposal by NL Industries, Inc., Colonie, N.Y. Governor's Task Force on NL, Albany, NY, USA.

Salbu, B., Janssens, K., Lind, O. C., Proost, K., Gijsels, L. \& Danesi, P. R. 2005. Oxidation states of uranium in depleted uranium particles from Kuwait. Journal of Environmental Radioactivity, 78 (2), 125-135.

Schimmack, W., Gerstmann, U., Oeh, U., Schultz, W. \& Schramel, P. 2005. Leaching of depleted uranium in soil as determined by column experiments. Radiation and Environmental Biophysics, 44 (3), 183-191.

Schuller, P., Ellies, A. \& Kirchner, G. 1997. Vertical migration of fallout ${ }^{137}$ Cs in agricultural soils from Southern Chile. Science of the Total Environment, 193 (3), 197-205.

Shen, C. C., Lawrence Edwards, R., Cheng, H., Dorale, J. A., Thomas, R. B., Bradley Moran, S., Weinstein, S. E. \& Edmonds, H. N. 2002. Uranium and thorium isotopic and concentration measurements by magnetic sector inductively coupled plasma mass spectrometry. Chemical Geology, 185 (3-4), 165-178.

Sheppard, S. C., Sheppard, M. I., Gallerand, M. O. \& Sanipelli, B. 2005. Derivation of ecotoxicity thresholds for uranium. Journal of Environmental Radioactivity, 79 (1), 55-83.

Sizmur, T. \& Hodson, M. E. 2009. Do earthworms impact metal mobility and availability in soil? - A review. Environmental Pollution, 157 (7), 1981-1989. 
Smith, R. F. 1984. Historical impact of reactor tails on the Paducah Cascade. Martin Marietta Energy Systems Inc. for the United States Department of Energy, Oak Ridge, TN, USA Report KY/L-1239.

Steiger, R. H. \& Jäger, E. 1977. Subcommission on geochronology: Convention on the use of decay constants in geo- and cosmochronology. Earth and Planetary Science Letters, 36 (3), 359-362.

Szabo, B. J. \& Rosholt, J. N. 1982. Surficial Continental Sediments. In: M. Ivabovich \& R. S. Harmon (eds) Uranium Series Disequilibrium: Applications to Environmental Problems. Clarendon Press, Oxford, UK.246-267.

Taylor, R. N., Croudace, I. W., Warwick, P. E. \& Dee, S. J. 1998. Precise and rapid determination of ${ }^{238} \mathrm{U} /{ }^{235} \mathrm{U}$ and uranium concentration in soil samples using thermal ionisation mass spectrometry. Chemical Geology, 144 (1-2), 73-80.

Taylor, S. R. 1964. Abundance of chemical elements in the continental crust: a new table. Geochimica et Cosmochimica Acta, 28 (8), 1273-1285.

The Royal Society 2001. The health hazards of depleted uranium munitions Part I. The Royal Society, London.

The Royal Society 2002. The health hazards of depleted uranium munitions Part II. The Royal Society, London.

Thompson, M. \& Howarth, R. J. 1978. A new approach to the estimation of analytical precision. Journal of Geochemical Exploration, 9 (1), 23-30.

Török, S., Osán, J., Vincze, L., Kurunczi, S., Tamborini, G. \& Betti, M. 2004. Characterization and speciation of depleted uranium in individual soil particles using microanalytical methods. Spectrochimica Acta - Part B Atomic Spectroscopy, 59 (5), 689-699.

US Department of Commerce 2001. TIGER/Line Files, Redistricting Census 2000. World Wide Web Address: http://arcdata.esri.com/data/tiger2000/ (13/03/2006).

USACE 2002. Final Status Survey Plan - Colonie FUSRAP Site. U.S. Army Corps of Engineers, New York District Office, New York Report DACW41-01-D-0031.

USACE 2009. Colonie Interim Storage Site (CISS) Fact Sheet. World Wide Web Address: http://www.nan.usace.army.mil/project/newyork/factsh/pdf/colonie.pdf (11/05/2009).

USDA 2006. Soil survey geographic database for Albany county, New York. U.S. Department of Agriculture, Natural Resources Conservation Services, Fort Worth, TX, USA.

USGS 2004. National Uranium Resource Evaluation (NURE) Hydrogeochemical and Stream Sediment Reconnaissance data (v. 1.40). U.S. Geological Survey, Denver, CO. World Wide Web Address: http://tin.er.usgs.gov/nure/sediment/ (22/12/2006).

WebMet.com 2002. Samson Surface Met Data. World Wide Web Address: http://www.webmet.com/State_pages/SAMSON/14735_sam.htm (10/08/2006).

Wendt, I. \& Carl, C. 1991. The statistical distribution of the mean squared weighted deviation. Chemical Geology: Isotope Geoscience Section, 86 (4), 275-285.

Weyer, S., Anbar, A. D., Gerdes, A., Gordon, G. W., Algeo, T. J. \& Boyle, E. A. 2008. Natural fractionation of ${ }^{238} \mathrm{U} /{ }^{235} \mathrm{U}$. Geochimica et Cosmochimica Acta, 72 (2), 345-359.

Wilkinson, W. D. 1962. Uranium Metallurgy. Interscience Publishers (John Wiley and Sons), New York.

Wolf, S. E. 1999. Analytical Methods for Determination of Uranium in Geological and Environmental Materials. In: P. C. Burns \& R. Finch (eds) Uranium: Mineralogy, Geochemistry and the Environment. Mineralogical Society of America, Washington, DC.623-652.

Zheng, J. \& Yamada, M. 2006. Determination of U isotope ratios in sediments using ICP-QMS after sample cleanup with anion-exchange and extraction chromatography. Talanta, 68 (3), 932939. 